\title{
Emission and chemistry of organic carbon in the gas and aerosol phase at a sub-urban site near Mexico City in March 2006 during the MILAGRO study
}

\author{
J. A. de Gouw ${ }^{1,2}$, D. Welsh-Bon ${ }^{1,2}$, C. Warneke ${ }^{1,2}$, W. C. Kuster $^{1}$, L. Alexander ${ }^{3}$, A. K. Baker ${ }^{4}$, A. J. Beyersdorf ${ }^{4, *}$, \\ D. R. Blake ${ }^{4}$, M. Canagaratna ${ }^{5}$, A. T. Celada ${ }^{6}$, L. G. Huey ${ }^{7}$, W. Junkermann ${ }^{8}$, T. B. Onasch ${ }^{5}$, A. Salcido ${ }^{6}$, \\ S. J. Sjostedt ${ }^{7, * *}$, A. P. Sullivan ${ }^{7, * * *}$, D. J. Tanner ${ }^{7}$, O. Vargas $^{7}$, R. J. Weber ${ }^{7}$, D. R. Worsnop ${ }^{5}$, X. Y. Yu ${ }^{3}$, and \\ R. Zaveri ${ }^{3}$ \\ ${ }^{1}$ NOAA Earth System Research Laboratory, Boulder, CO, USA \\ ${ }^{2}$ Cooperative Institute for Research in Environmental Sciences, University of Colorado, Boulder, CO, USA \\ ${ }^{3}$ Pacific Northwest National Laboratory, Richland, WA, USA \\ ${ }^{4}$ University of California, Irvine, CA, USA \\ ${ }^{5}$ Aerodyne Research Inc., Billerica, MA, USA \\ ${ }^{6}$ Instituto de Investigaciones Eléctricas, Cuernavaca, Morelos, Mexico \\ ${ }^{7}$ Georgia Institute of Technology, Atlanta, GA, USA \\ ${ }^{8}$ Research Center Karlsruhe - Institute for Meteorology and Climate Research, Garmisch-Partenkirchen, Germany \\ *now with: NASA Langley Research Center, Hampton, VA, USA \\ ${ }^{* *}$ now with: Department of Chemistry, University of Toronto, Toronto, ON, Canada \\ **** now with: Department of Atmospheric Science, Colorado State University, Fort Collins, CO, USA
}

Received: 7 October 2008 - Published in Atmos. Chem. Phys. Discuss.: 23 December 2008

Revised: 17 April 2009 - Accepted: 15 May 2009 - Published: 28 May 2009

\begin{abstract}
Volatile organic compounds (VOCs) and carbonaceous aerosol were measured at a sub-urban site near Mexico City in March of 2006 during the MILAGRO study (Megacity Initiative: Local and Global Research Objectives). Diurnal variations of hydrocarbons, elemental carbon (EC) and hydrocarbon-like organic aerosol (HOA) were dominated by a high peak in the early morning when local emissions accumulated in a shallow boundary layer, and a minimum in the afternoon when the emissions were diluted in a significantly expanded boundary layer and, in case of the reactive gases, removed by $\mathrm{OH}$. In comparison, diurnal variations of species with secondary sources such as the aldehydes, ketones, oxygenated organic aerosol (OOA) and watersoluble organic carbon (WSOC) stayed relatively high in the afternoon indicating strong photochemical formation. Emission ratios of many hydrocarbon species relative to $\mathrm{CO}$ were higher in Mexico City than in the U.S., but we found similar emission ratios for most oxygenated VOCs and organic aerosol. Secondary formation of acetone may be more efficient in Mexico City than in the U.S., due to higher emissions
\end{abstract}

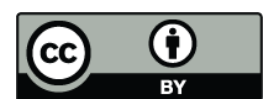

of alkane precursors from the use of liquefied petroleum gas. Secondary formation of organic aerosol was similar between Mexico City and the U.S. Combining the data for all measured gas and aerosol species, we describe the budget of total observed organic carbon (TOOC), and find that the enhancement ratio of TOOC relative to $\mathrm{CO}$ is conserved between the early morning and mid afternoon despite large compositional changes. Finally, the influence of biomass burning is investigated using the measurements of acetonitrile, which was found to correlate with levoglucosan in the particle phase. Diurnal variations of acetonitrile indicate a contribution from local burning sources. Scatter plots of acetonitrile versus $\mathrm{CO}$ suggest that the contribution of biomass burning to the enhancement of most gas and aerosol species was not dominant and perhaps not dissimilar from observations in the U.S.

\section{Introduction}

Ozone and particulate matter (PM) are two of the main air pollutants of concern in large urban areas. Ozone is a by-product of the photo-oxidation of volatile organic compounds (VOCs) in the presence of nitrogen oxides. Particulate matter (PM) has both direct emission sources and is also

Published by Copernicus Publications on behalf of the European Geosciences Union. 


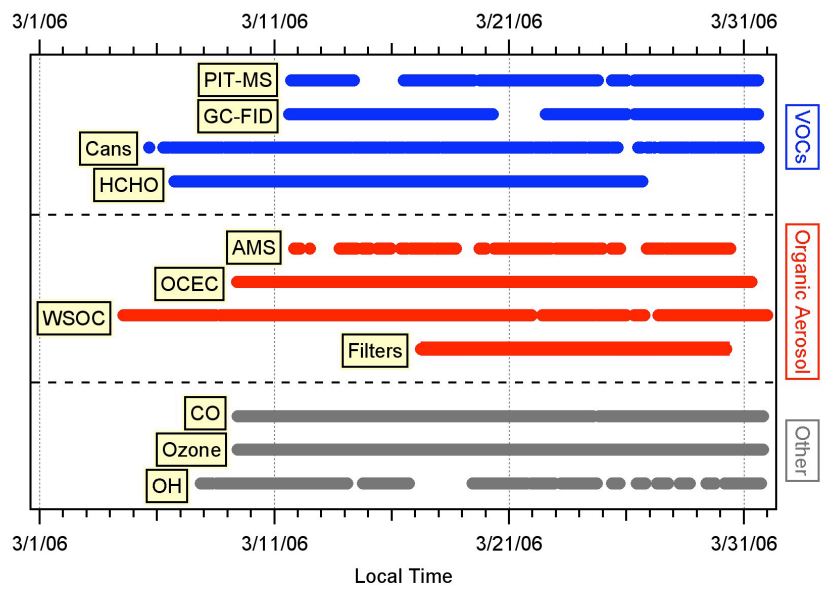

Fig. 1. Status of the instruments that were used to measure VOCs, organic aerosol, $\mathrm{CO}$, ozone and $\mathrm{OH}$ at the ground site $\mathrm{T} 1$.

formed in the atmosphere from chemistry involving several organic and inorganic species. The MILAGRO (Megacity Initiative: Local and Global Research Objectives) study was initiated to characterize the pollutant emissions from Mexico City, and their transformation and impact on the atmosphere from local to global scales. The study involved multiple ground sites inside and downwind from Mexico City, as well as multiple research aircraft. In this study, we will focus on the emissions and chemistry of organic carbon in the combined gas and particle phases, and focus on the chemical transformation at the local scale.

Earlier work on the emissions and chemistry of VOCs in Mexico City showed the presence of very large emissions of small alkanes, presumably from the use of liquefied petroleum gas used in households (Blake and Rowland, 1995). Detailed VOC measurements were obtained during a mission in Mexico City in 2003 (Velasco et al., 2007). Eddycovariance measurements of several hydrocarbon and oxygenated species were obtained inside the city (Velasco et al., 2005), emissions from vehicles were directly sampled using a mobile laboratory (Zavala et al., 2007), and measurements of formaldehyde and glyoxal gave detailed insight into the daytime chemical processing (Volkamer et al., 2005; Garcia et al., 2006).

The formation of secondary organic aerosol (SOA) in urban air has received much attention in the past few years. The advent and widespread use of aerosol mass spectrometry (AMS) as well as measurements of water-soluble organic carbon (WSOC) have indicated that much of the organic aerosol in urban areas is likely secondary rather than primary (de Gouw et al., 2005; Sullivan et al., 2006; Volkamer et al., 2006; Weber et al., 2007; Zhang et al., 2007; de Gouw et al., 2008; Docherty et al., 2008; Herndon et al., 2008). Several studies, including in Mexico City, showed that the observed SOA formation could not be explained quantitatively from the measured VOCs and their laboratory-determined particulate yields (de Gouw et al., 2005; Volkamer et al., 2006; de Gouw et al., 2008; Kleinman et al., 2008). The reasons are still unknown, but may include (i) SOA formation from semi-volatile organic compounds (SVOCs) (Robinson et al., 2007), (ii) increased SOA yields at the NOx levels typically observed in the atmosphere ( $\mathrm{Ng}$ et al., 2007), and (iii) the enhanced formation of SOA from biogenic VOCs in urban air (Weber et al., 2007). In addition, cloud-modified formation of SOA has received much attention as well (Ervens et al., 2008), but does most likely not explain the discrepancy between measured and calculated SOA, since the aforementioned studies focused on clear air conditions. Because of the close connection between VOCs and SOA there is an increasing number of studies that address the budget and speciation of total organic carbon in the combined gas and aerosol phases (de Gouw et al., 2005; Goldstein and Galbally, 2007; Heald et al., 2008).

Here we study organic carbon in the combined gas and aerosol phases using data from the sub-urban T1 site in Mexico City during MILAGRO. The T1 site was located $\sim 30 \mathrm{~km}$ to the northeast of the center of Mexico City on the campus of the Technical University of Tecámac and was chosen as part of a T0-T1-T2 series of sites to capture outflow from Mexico City to the northeast after different transport times (Doran et al., 2007; Fast et al., 2007). The Mexico City urban area extends to T1: local emissions were not insignificant and likely dominated during the night and early morning. Using observed diurnal variations, the primary emissions and secondary formation of VOCs and of organic aerosol can be distinguished from each other, and the results are compared with findings obtained in the U.S. The results from multiple instruments are used to compare the total observed organic carbon (TOOC) (Heald et al., 2008) between the morning and afternoon. Finally, the influence of biomass burning on the measurements of VOCs and organic aerosol is discussed using the measurements of acetonitrile. Previous estimates of the influence of biomass burning on the emissions in and around Mexico City are highly variable (Yokelson et al., 2007; DeCarlo et al., 2008; Moffet et al., 2008; Querol et al., 2008; Stone et al., 2008).

\section{Measurements}

Multiple instruments were used at T1 to measure VOCs and organic aerosol. Figure 1 shows when the different instruments were operational. Brief descriptions of the different instruments used are given next.

\subsection{Volatile organic compounds}

An on-line gas chromatograph with flame-ionization detection (GC-FID) was used to measure several different hydrocarbon species (see Table 1). The measurement cycle included a 5-min sampling period, followed by a $10-\mathrm{min}$ 
chromatographic run. The instrument has been described elsewhere in more detail (Kuster et al., 2004). The measurement accuracy was about $10 \%$ for all species measured.

A proton-transfer-reaction ion trap mass spectrometry (PIT-MS) instrument was used for on-line measurements of several organic species (Warneke et al., 2005a, 2005b). The PIT-MS is a home-built instrument that uses proton-transfer reactions in a drift tube to ionize VOCs, similar to PTR-MS (de Gouw and Warneke, 2007), and an ion trap mass spectrometer to mass select and detect the ions. The species reported from MILAGRO are shown in Table 1. The data were averaged over 5 -min periods for improved precision and easy comparison with the on-line GC-FID instrument. Measurement accuracies were around 25\% for all species except $50 \%$ for acetic acid. More details on the PIT-MS measurements during MILAGRO, including data inter-comparisons with other instruments, are presented elsewhere (Welsh-Bon et al., 2008).

Canister samples were collected at $\mathrm{T} 1$, and analyzed for numerous alkanes, alkenes, aromatics and halocarbons using GC-MS and other methods at the University of California at Irvine. At T1, eight samples per day were collected on average, and the fill time was around $3 \mathrm{~h}$ per sample. Many of the species measured from the canisters were also quantified by the NOAA GC-FID and PIT-MS instruments; the data are compared elsewhere (Welsh-Bon et al., 2008). The NOAA GC-FID and PIT-MS data are used in this study because of their higher measurement frequency. Table 1 shows the species that were quantified from the canisters only and that were used in this study.

Formaldehyde (HCHO) was measured using the Hantzsch method, which involves the derivatization of formaldehyde using 2,4-pentanedione and ammonium acetate in the socalled Hantzsch reaction (Junkermann and Burger, 2006). The detection is accomplished using fluorescence spectroscopy after excitation with an $\mathrm{Hg}$ lamp. Data was reported at 2-min time intervals with an uncertainty of $12 \%$ or $0.2 \mathrm{ppbv}$, whichever number was larger. Formaldehyde measurements by this method have been inter-compared versus other techniques both in urban conditions (Milan, Italy) (Hak et al., 2005) and in the simulation chamber SAPHIR (Wisthaler et al., 2008).

\subsection{Organic aerosol}

The mass of organic aerosol (OM) was measured using an aerosol time-of-flight mass spectrometry (C-ToF-AMS) instrument (Aerodyne Research) that is owned and operated by the Pacific Northwest National Laboratory (PNNL). The Aerodyne aerosol mass spectrometer was recently reviewed (Canagaratna et al., 2007) and more details on the use of time-of-flight mass spectrometers in AMS are given elsewhere (Drewnick et al., 2005; DeCarlo et al., 2006). Mass loadings of organics, sulfate, nitrate and ammonium were reported at ambient temperature and pressure and at 5-min
Table 1. VOC measurements used from the different instruments.*

\begin{tabular}{lll}
\hline NOAA GC-FID & NOAA PIT-MS & UCI Canisters ${ }^{\#}$ \\
propane & Alkanes & ethane \\
n-butane & n-heptane \\
i-butane & n-octane \\
n-pentane & n-nonane \\
i-pentane & n-decane \\
n-hexane & 2,2-dimethyl butane \\
& 2,3-dimethyl butane \\
& 2-methyl pentane \\
& 3-methyl pentane \\
& 2,4-dimethyl pentane \\
& 2,2,4-trimethyl pentane \\
& 2,3,4-trimethyl pentane \\
\hline & \\
ethene & 1,3-butadiene \\
propene & isoprene \\
1-butene & \\
c-2-butene & Alkenes \\
t-2-butene & \\
2-methyl propene & \\
1-pentene & \\
c-2-pentene & \\
t-2-pentene & \\
2-methyl-1-butene & \\
3-methyl-1-butene & \\
2-methyl-2-butene & \\
\hline
\end{tabular}

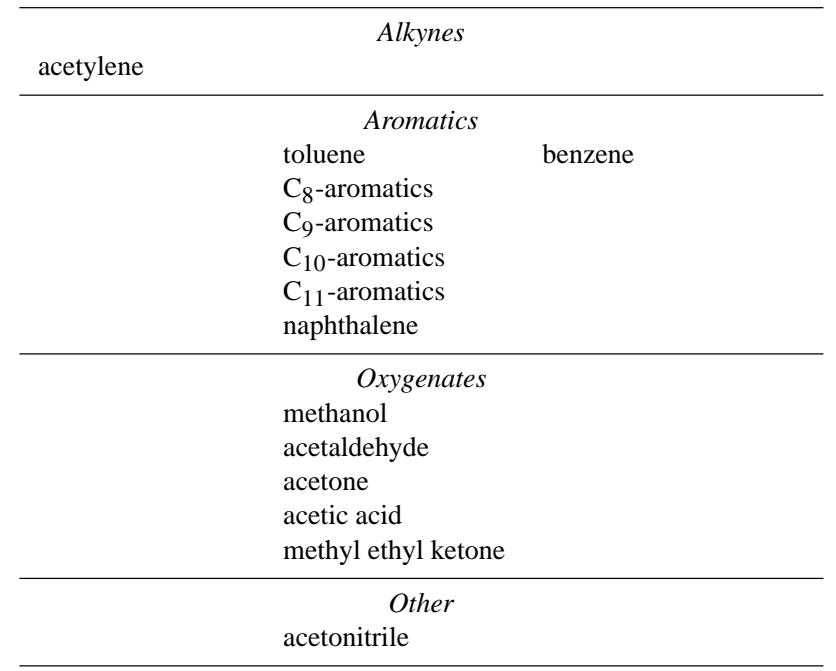

* Omitted from this table are the formaldehyde measurements using the Hantzsch method.

\# Many other species were measured from the UCI canisters; these are the measurements used in this work.

intervals with an estimated accuracy of $25 \%$. Data were compared with those from an AMS onboard the Aerodyne mobile laboratory (Herndon et al., 2008) when it was at T1 on 2123 March. A collection efficiency of 0.5 was assumed for the whole data set, based on comparisons with other particle size and composition measurements at $\mathrm{T} 1$ and onboard the Aerodyne mobile laboratory. This assumption is supported 


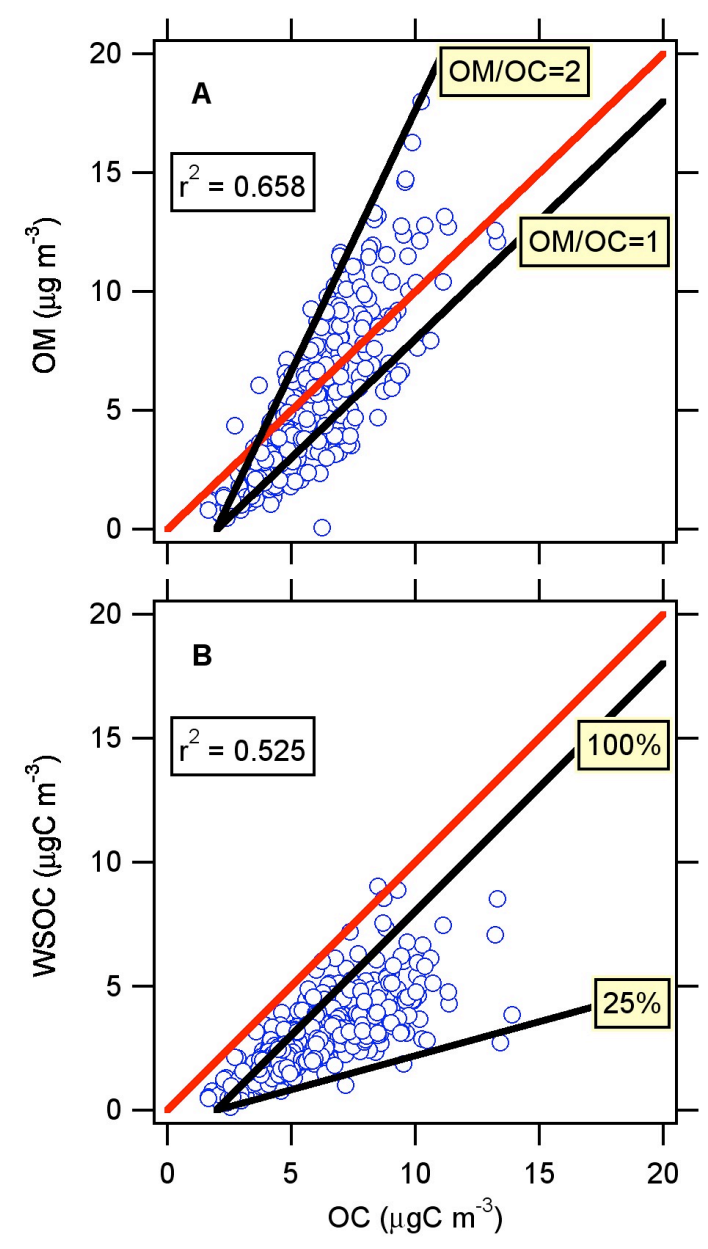

Fig. 2. Comparison between measured data for organic mass (OM), organic carbon (OC) and water-soluble organic carbon (WSOC). The red lines indicate the 1:1 relationships. The black lines indicate the expected range of data if there were an offset of $2 \mu \mathrm{gC} \mathrm{m}^{-3}$ in the OC data.

by inter-comparisons between AMS and other measurements elsewhere in Mexico City during MILAGRO (Salcedo et al., 2006; DeCarlo et al., 2008; Johnson et al., 2008; Kleinman et al., 2008). The mass spectral information was analyzed with positive matrix factorization (Lanz et al., 2007; Ulbrich et al., 2009) to separate hydrocarbon-like organic aerosol (HOA) and oxygenated organic aerosol (OOA) species (Zhang et al., 2005a).

Measurements of organic carbon (OC) and elemental carbon (EC) were made using a Sunset Laboratories OCEC analyzer that was operated following the NIOSH method 5040 (Eller and Cassinelli, 1996). Samples were collected onto the internal filter for 45 minutes, and the total measurement cycle lasted $1 \mathrm{~h}$. Overall accuracy of the measurement was estimated to be $20 \%$ (Peltier et al., 2007).

Water-soluble organic carbon (WSOC) was measured every 6 minutes by a particle-into-liquid sampler (PILS) coupled with a total organic carbon (TOC) analyzer (Sullivan et al., 2004; Peltier et al., 2007). More details on the measurements of WSOC obtained during MILAGRO are given elsewhere (Hennigan et al., 2008).

In addition to the measurements of OM, OC and WSOC, we use here the measurements of levoglucosan that was determined from filter samples as reported elsewhere (Stone et al., 2008). Particles were collected onto quartz fiber filters for 24-h sampling times. Solvent extractable organic species were measured from the samples using GC-MS.

All organic aerosol measurements are reported here for ambient conditions. It should be noted that mass loadings differ significantly between ambient and standard conditions (STP=273 K and 1013 mbar). As an example, at a temperature of $298 \mathrm{~K}$, the average daytime high at T1, and a pressure of $767 \mathrm{mbar}$, the average surface pressure at T1, the ambient mass loadings are a factor of 1.44 lower than mass loadings reported at STP. This should be kept in mind when comparing the results of this study to those of aircraft measurements, which are commonly reported at STP.

Figure 2 shows a comparison between the measurements of OM, OC and WSOC. Figure 2 a shows that OM was lower than OC for many samples. There can be different explanations for this discrepancy. First, the $50 \%$ cut point for large particles for the AMS was approximately $800-\mathrm{nm}$ in vacuum aerodynamic diameter at an ambient pressure of $767 \mathrm{mbar}$ (Liu et al., 2007b), whereas the OCEC measurement covered the $2.5-\mu \mathrm{m}$ size range. The measurement of OC could be higher than that of OM if a significant part of the mass was above the size cut-off of the AMS. This is typically not the case (de Gouw et al., 2005, 2008; Kondo et al., 2007), and other data from Mexico City also do not indicate $>20 \%$ of PM2.5 mass to be in the $1-2.5 \mu \mathrm{m}$ size range (Salcedo et al., 2006; Johnson et al., 2008; Querol et al., 2008). Second, it has been suggested that OC measurements can suffer from positive biases due to the accumulation of semi volatiles on the filter (Offenberg et al., 2007); for the data from T1 it was estimated that this bias could be as high as $3.6 \mu \mathrm{gC} \mathrm{m}^{-3}$ (Peltier et al., 2007). Indeed, an offset in the OC measurement could mostly explain the discrepancy with the OM measurement: the black lines in Fig. 2a represent the expected range of $\mathrm{OM} / \mathrm{OC}$ ratios of 1 to $2 \mu \mathrm{g} \mu \mathrm{gC}^{-1}$ (Turpin and Lim, 2001; de Gouw et al., 2008), assuming an offset in OC of $2 \mu \mathrm{gC} \mathrm{m}^{-3}$. It is seen that most of the data are within this expected range. Third, the difference could be due to calibration problems with the AMS and/or organic carbon measurements. The difference would have to be large, however, and larger than typically observed for these measurements (de Gouw et al., 2005, 2008; Takegawa et al., 2005; Salcedo et al., 2006; Kondo et al., 2007; DeCarlo et al., 2008).

Figure $2 \mathrm{~b}$ shows that for most samples WSOC was smaller than $\mathrm{OC}$, with the line corresponding to WSOC $=\mathrm{OC}$ acting as an upper limit to the distribution. The data are not inconsistent with an offset in the OC measurement of $2 \mu \mathrm{gC} \mathrm{m}^{-3}$. The expected range for the WSOC and OC 

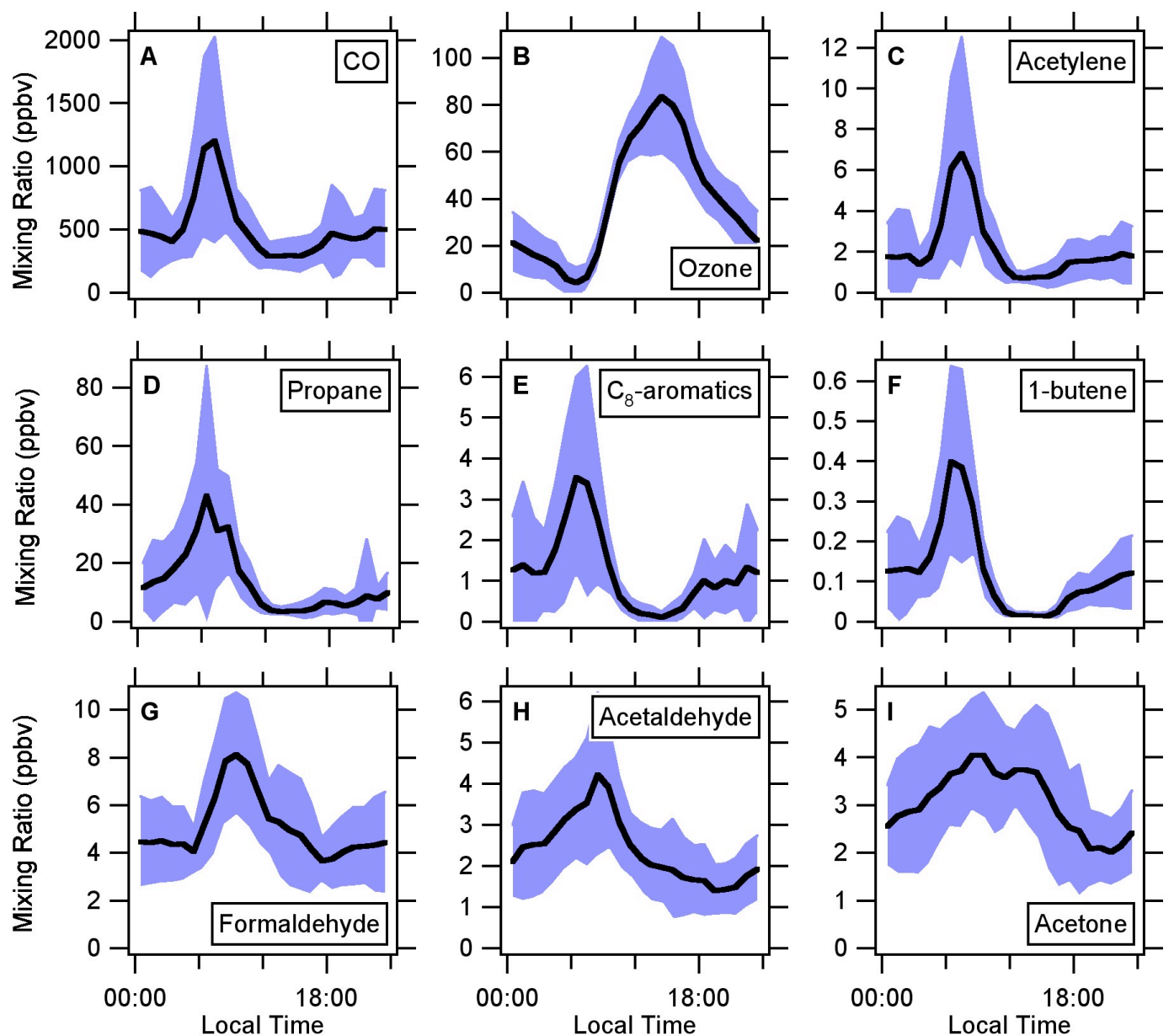

Fig. 3. Diurnal variations of selected gas-phase species at the T1 site during MILAGRO. The black lines indicate the mean mixing ratios in hourly bins, and the blue shaded areas indicate the standard deviations in these hourly means.

data corresponding to water-soluble fractions between 25 and $100 \%$ (Sullivan et al., 2004) is represented by the two black lines in Fig. 2b. Most of the data in Fig. 2b are within this expected range.

\subsection{Other measurements}

Other measurements used in this study are those of ozone $\left(\mathrm{O}_{3}\right)$, carbon monoxide $(\mathrm{CO})$ and hydroxyl radicals $(\mathrm{OH})$. Ozone was measured with a commercial UV photometric analyzer (TECO, Model 49C). Measurements of CO were obtained every minute with a $50 \%$ duty cycle using a commercial non-dispersed infrared absorption instrument (Thermo Environmental Systems, Model 48C). $\mathrm{OH}$ was measured by chemical ionization mass spectrometry (CIMS) (Sjostedt et al., 2007) and reported on a 5-min time scale and with an uncertainty of $25 \%$.

\section{Results and discussion}

\subsection{Diurnal variations of VOCs and organic aerosol}

The diurnal variations for most species were pronounced. Figure 3 shows examples for some selected gas-phase species and Fig. 4 for different carbonaceous aerosol species. The diurnal variations are calculated from the entire data set, even though the different measurements did not cover the exact same periods (Fig. 1). Limiting the analysis to periods when all measurements were available, would reduce the data set too severely.

Primary species such as $\mathrm{CO}$, acetylene, propane, the $\mathrm{C}_{8}$ aromatics and 1-butene peaked in the early morning (Fig. 3), when nighttime emissions accumulated in a shallow boundary layer in the absence of efficient chemical removal. Diurnal variations in the emissions of these species, for example due to rush-hour traffic, also affect the observed diurnal variations but are not likely responsible for the large early-morning peak. After sunrise, the mixing ratios of the 

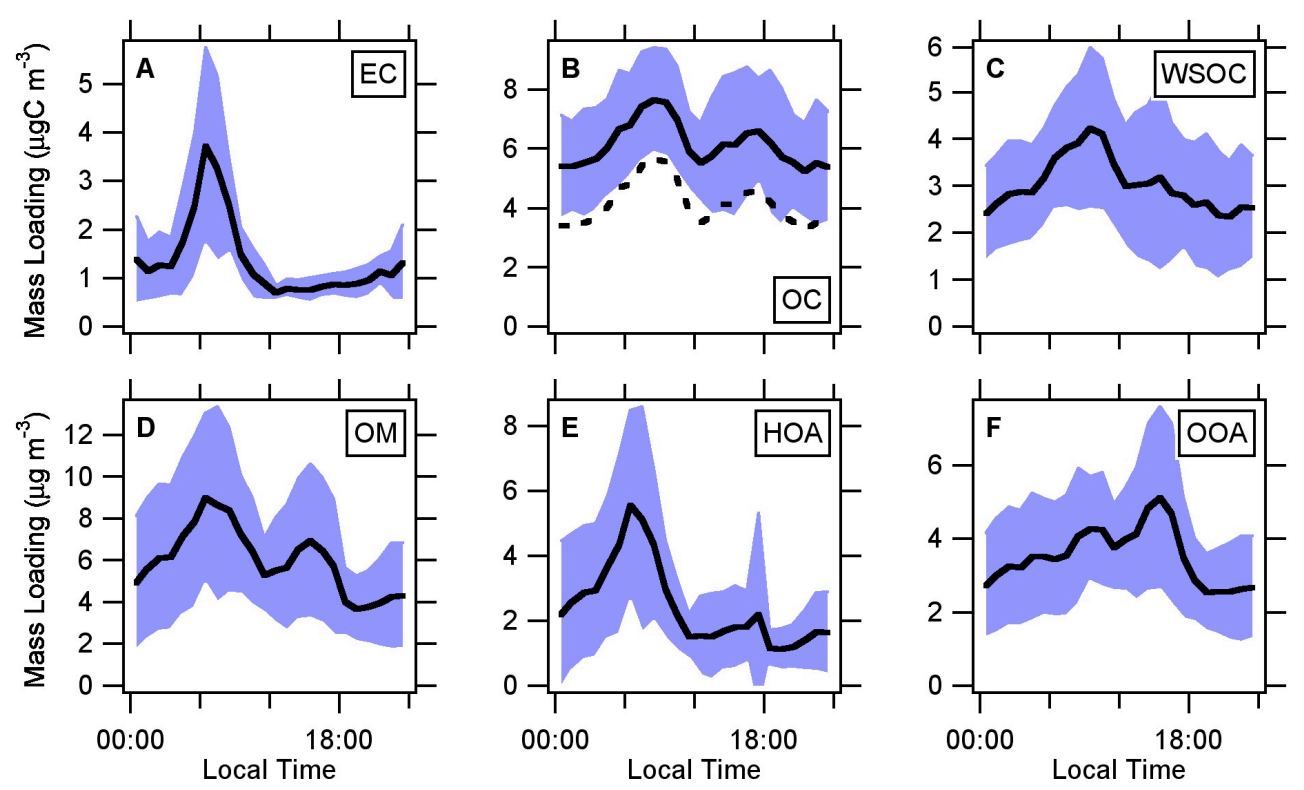

Fig. 4. Diurnal variations of organic aerosol data from the T1 site during MILAGRO. The black lines indicate the mean mass loadings in hourly bins, and the blue shaded areas indicate the standard deviations in these hourly means. The black dashed line in panel B indicates the diurnal variation assuming an offset of $2 \mu \mathrm{gC} \mathrm{m}^{-3}$ in the OC measurement.

primary species decreased quickly by dilution in a rapidly expanding boundary layer (Shaw et al., 2007), and by reactions with $\mathrm{OH}$ for reactive species such as the $\mathrm{C}_{8}$-aromatics and 1butene. Similar diurnal variations for primary hydrocarbons have been reported for several sites inside the city boundaries (Velasco et al., 2007; Fortner et al., 2008). Ozone was typically titrated by $\mathrm{NO}_{\mathrm{x}}$ in the early morning and then increased to an average of around $80 \mathrm{ppbv}$ in the mid afternoon.

Species with secondary sources such as formaldehyde, acetaldehyde and acetone showed maxima in the morning, though slightly later than the primary species. There was no strong decrease of acetone during the day, as observed for the primary species, which indicates a strong secondary formation during the day or the mixing with air aloft that was enriched in acetone. The latter possibility is less likely, however, since the diurnal variations in longer-lived, primary species (CO, acetylene) did not show the same diurnal trend. Formaldehyde and acetaldehyde also stayed relatively high during the day. These species are so reactive $(\mathrm{OH}$ rate coefficients are $9.37 \times 10^{-12} \mathrm{~cm}^{3}$ molecule ${ }^{-1} \mathrm{~s}^{-1}$ for formaldehyde and $15 \times 10^{-12} \mathrm{~cm}^{3}$ molecule ${ }^{-1} \mathrm{~s}^{-1}$ for acetaldehyde) (Atkinson and Arey, 2003) that in the absence of secondary formation, they would go to very low mixing ratios in the afternoon, similarly to the $\mathrm{C}_{8}$-aromatics $(\mathrm{OH}$ rate coefficients range from $7.0 \times 10^{-12} \mathrm{~cm}^{3}$ molecule ${ }^{-1} \mathrm{~s}^{-1}$ for ethyl benzene to $23.1 \times 10^{-12} \mathrm{~cm}^{3}$ molecule ${ }^{-1} \mathrm{~s}^{-1}$ for m-xylene) (Atkinson and Arey, 2003). The observation that they remain high during the day indicates a large contribution from secondary formation, in agreement with the results from previous studies (de Gouw et al., 2005; Liu et al., 2007a).
Figure 4 shows the diurnal variations of the different carbonaceous aerosol measurements. Species that are directly emitted, EC and HOA, have very similar diurnal variations as the primary gas-phase species in Fig. 3 with a maximum around 06:00 a.m. The diurnal variations of OC, WSOC, $\mathrm{OM}$ and OOA, on the other hand, are much more similar to that of acetone in Fig. 3. OC, WSOC and OM in particular show a maximum in the morning, although later than the primary species, and remain high during the day, indicating a strong secondary formation of these species. In Fig. 4 the OC data are used as reported; if there were an offset in the measurement of OC, the diurnal variation would be reduced by $2 \mu \mathrm{gC} \mathrm{m}^{-3}$ at all times of the day (black dashed curve in Fig. 4b).

One could expect to find diurnal variations in the WSOC/OC and the OM/OC ratios. In the early morning, when the sampled air contained high primary emissions, one would expect that $\mathrm{OM}$ is only slightly higher than $\mathrm{OC}$ (Turpin and Lim, 2001) and that the water-soluble fraction of OC is low (Sullivan et al., 2004). In the afternoon, when the sampled air masses were more processed, the OM/OC and WSOC/OC ratios are both expected to be higher than in the early morning. These expected diurnal variations were not evident from the data.

Figure 5 shows the distribution of wind directions and measured $\mathrm{CO}$ during the early morning and mid-afternoon. Early morning winds were very light at $\mathrm{T} 1\left(<1 \mathrm{~m} \mathrm{~s}^{-1}\right.$ on average) and mostly from the east-southeast (Fig. 5a), possibly driven by the terrain. Average measured $\mathrm{CO}$ was high $(>1$ ppmv) over a large range of easterly wind directions 

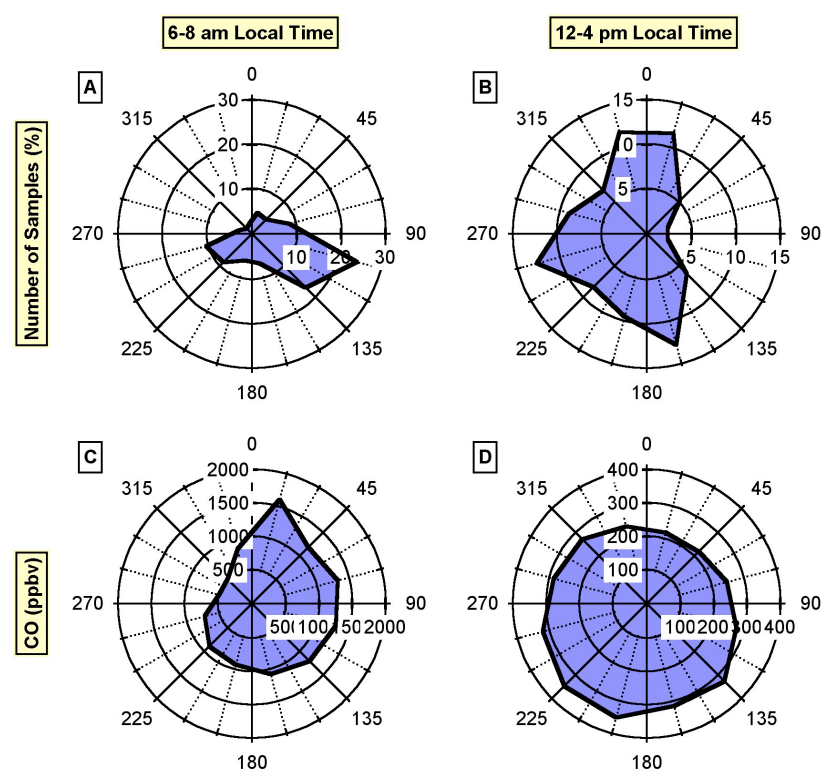

Fig. 5. Distribution of wind directions (panels (a) and (b)) and measured CO (panels (c) and (d)) during the early morning (panels (a) and (c)) and mid-afternoon (panels (b) and (d)) periods. Data in low and variable winds were omitted by requiring a minimum wind speed of $0.5 \mathrm{~m} \mathrm{~s}^{-1}$.

(Fig. 5c), and highest from the north-northeast, possibly from the near-by town of Tecámac. Combined with the low wind speeds, we conclude that mostly local emissions were sampled during the early morning. Mid-afternoon winds were higher on average (3-5 $\mathrm{m} \mathrm{s}^{-1}$ on average) and coming from the north, west-southwest and south-southeast (Fig. 5b). CO and other anthropogenic trace gases were highest from the south-southwest, i.e. the direction of Mexico City, although not strongly dependent on wind direction (Fig. 5d). At the observed wind speeds, emissions were transported in $2-3 \mathrm{~h}$ from the center of Mexico City to T1. The relatively uniform distribution of average $\mathrm{CO}$ suggests that part of the observed pollutants had a more regional character, possibly due to recirculation of Mexico City emissions from previous days.

\subsection{Emission ratios of VOCs and organic aerosol}

Most hydrocarbons correlated very well with CO; examples for some selected gas-phase species are shown in Fig. 6. Good correlations were observed for relatively inert species such as acetylene $\left(r^{2}=0.869\right)$, but also for much more reactive species such as the $\mathrm{C}_{8}$-aromatics $\left(r^{2}=0.767\right)$ and 1 butene $\left(r^{2}=0.850\right)$. The latter has not always been observed in other field studies, because the $\mathrm{C}_{8}$-aromatics and 1-butene are removed much more rapidly than $\mathrm{CO}$, leading to a loss of correlation in air masses that are more aged (de Gouw et al., 2005). However, in the present data set the highest mixing ratios of VOCs and $\mathrm{CO}$ are driven by the observations in the early morning when chemical removal was inefficient.
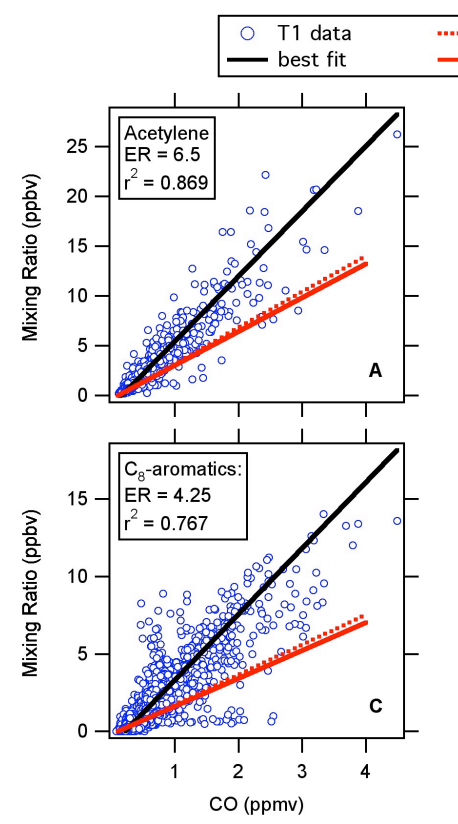

Warneke et al. [2007] - Baker et al. [2008]
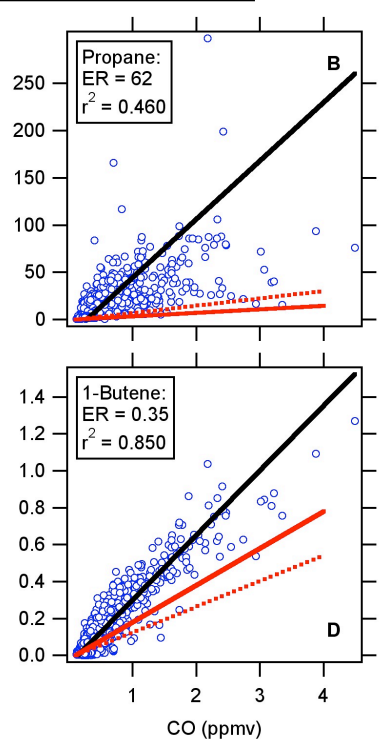

Fig. 6. Scatter plots of (a) acetylene, (b) propane, (c) $\mathrm{C}_{8}$-aromatics and (d) 1-butene versus $\mathrm{CO}$ at the $\mathrm{T} 1$ site during MILAGRO. Emission ratios versus $\mathrm{CO}(\mathrm{ER})$ are given in units of ppbv ppmv ${ }^{-1}$.

Emission ratios of VOCs relative to $\mathrm{CO}$ were determined by 2 -sided regression fits to the data. The black lines in Fig. 6 show the results and the emission ratios (ER) are given in the legends in units of ppbv ppmv ${ }^{-1}$. For most species, the emission ratios in Mexico City were higher than in the U.S. As an example, the red lines in Fig. 6 represent the emission ratios from two recent studies: the dotted lines are from a shipbased study off the U.S. East coast (Warneke et al., 2007), and the solid lines are from a study summarizing data from 28 U.S. cities (Baker et al., 2008). It is seen that the two U.S. studies agree well with each other, but the data measured in Mexico City follow a significantly steeper trend for all hydrocarbon species in Fig. 6. This was true for almost all hydrocarbon species measured and is discussed in more detail in another paper (Welsh-Bon et al., 2008).

Very large mixing ratios of short-chain alkanes such as propane and butane were observed in Mexico City. Figure 6b shows multiple samples with propane mixing ratios over $50 \mathrm{ppbv}$ and the highest observed value was over $250 \mathrm{ppbv}$. The source of alkanes is likely from the leakage of liquefied petroleum gas used in households, as reported earlier (Blake and Rowland, 1995). CO comes from combustion sources and, as a result, the degree of correlation between $\mathrm{CO}$ and propane was not very high $\left(r^{2}=0.460\right.$; Fig. $\left.6 \mathrm{~b}\right)$. The emission ratios for these species are not well determined by the data and are, therefore, not very meaningful parameters. 

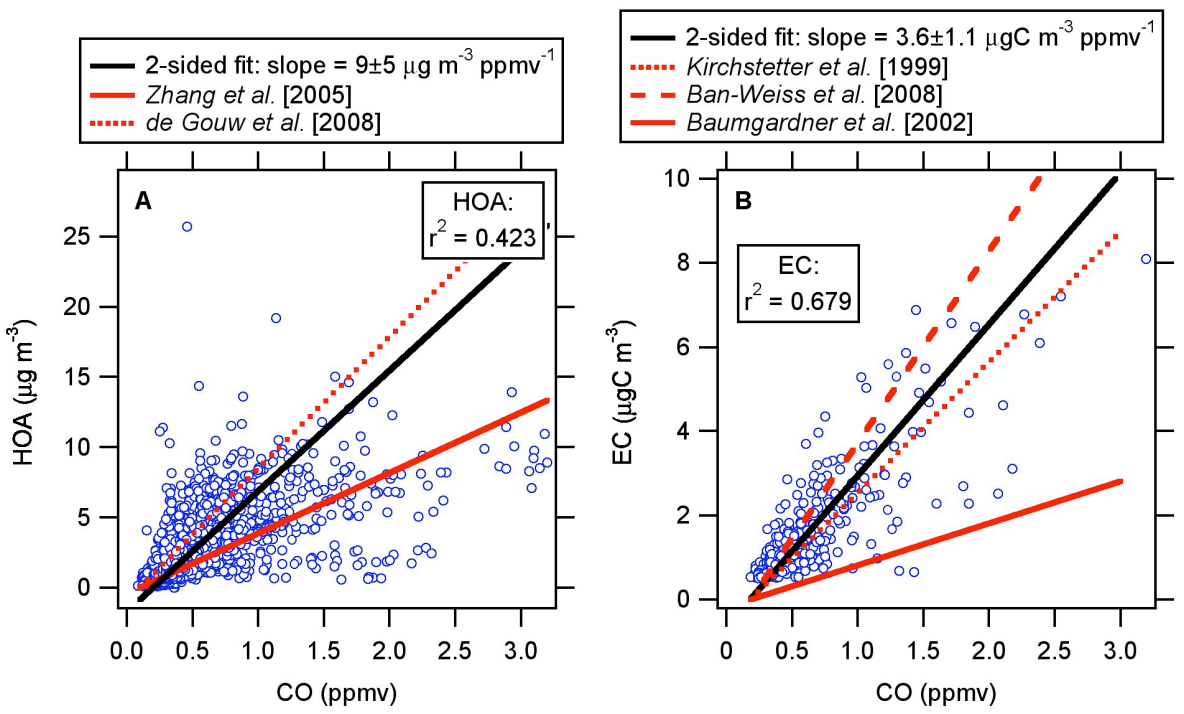

Fig. 7. Scatter plots of (a) hydrocarbon-like organic aerosol (HOA) and (b) elemental carbon (EC) versus CO at the T1 site during MILAGRO.

Figure 7 shows scatter plots of the primary aerosol species HOA and EC versus CO. The degree of correlation between HOA and CO was not very high $\left(r^{2}=0.423\right.$; Fig. 7a) and much lower than reported elsewhere (Zhang et al., 2005b). The degree of correlation was higher for shorter periods of the study: for example, for a 4-day period near the end of the study (27-30 March), HOA and CO were correlated with an $r^{2}$ of 0.631 . A possible explanation may be a contribution from biomass and trash burning; more on this in the next section. Nevertheless, a 2-sided regression fit through the data had a slope of $9 \pm 5 \mu \mathrm{g} \mathrm{m}^{-3} \mathrm{ppmv}^{-1}$ (black line in Fig. 7a) in agreement with estimates from several other studies (Zhang et al., 2005b; Lanz et al., 2006; Takegawa et al., 2006; de Gouw et al., 2008; Kleinman et al., 2008).

The degree of correlation between EC and $\mathrm{CO}$ was higher $\left(r^{2}=0.679\right.$; Fig. 7b). The data in Fig. $7 \mathrm{~b}$ are overlaid with the result from an earlier study in Mexico City in 2000 (red solid line, corresponding to an EC/CO ratio of $1.1 \mu \mathrm{g} \mathrm{mg}^{-1}$ or $1.0 \mu \mathrm{gC} \mathrm{m}^{-3} \mathrm{ppmv}^{-1}$ ) (Baumgardner et al., 2002); the present data clearly follow a significantly steeper trend. Because the on-road sources of CO (mostly gasoline) and EC (mostly Diesel) are different, the ratio between the two species is highly dependent on the average composition of the vehicle fleet, which may have been different at the suburban T1 site and the urban sites in the earlier study. The data in Fig. 7b are also overlaid with the results from 2 tunnel studies in the U.S. (Kirchstetter et al., 1999; Ban-Weiss et al., 2008), which agree much better with the data from T1.

\subsection{Influence of biomass burning}

Mixing ratios of acetonitrile, a gas-phase indicator of biomass burning emissions, were high compared to U.S. urban areas and peaked in the early morning (Fig. 8a). It seems likely therefore that biomass burning contributed to the emissions in Mexico City; the peak in the early morning indicates that part of these emissions were local and likely from the domestic use of bio-fuels and/or from the burning and smoldering of grasses and weeds, which was commonly observed in the area. Also, it cannot be ruled out entirely that motor vehicles are a source of acetonitrile in Mexico City, although previous studies have suggested this to be a minor source (Holzinger et al., 2001).

Figure $8 \mathrm{~b}$ shows a scatter plot of acetonitrile versus CO. Previous work has shown that the ratio between acetonitrile and $\mathrm{CO}$ is very different in forest fire and in urban plumes. The average $\Delta \mathrm{CH}_{3} \mathrm{CN} / \Delta \mathrm{CO}$ ratio in fire plumes is around 2.4 ppbv ppmv $^{-1}$ (red dotted line in Fig. 8b) (de Gouw et al., 2003, 2006; Warneke et al., 2006), whereas the $\Delta \mathrm{CH}_{3} \mathrm{CN} / \Delta \mathrm{CO}$ ratio in urban plumes is much lower: we found $\Delta \mathrm{CH}_{3} \mathrm{CN} / \Delta \mathrm{CO}$ to be $<0.1 \mathrm{ppbv} \mathrm{ppmv}^{-1}$ over Los Angeles and $0.25 \mathrm{ppbv} \mathrm{ppmv}^{-1}$ in a plume from New York City (red solid line in Fig. 8b) (de Gouw et al., 2006). The data from Mexico City follow the trend from New York City much better than the trend from forest fires, which indicates that biomass burning emissions are a smaller source of $\mathrm{CO}$ at $\mathrm{T} 1$ than vehicle emissions. Two data points at acetonitrile mixing ratios of 4-6 ppbv were obtained when emissions from a local grass fire were sampled at the site; these data follow the trend from the U.S. forest fires. At lower mixing ratios of acetonitrile and $\mathrm{CO}$, many data points follow the dotted line corresponding to biomass burning emissions. Kleinman et al. (2008) presented a similar analysis as shown here in Fig. 8b using data from the DOE G-1 aircraft. In their data set, the biomass burning influence was more pronounced as the aircraft sampled emissions from fires in the mountains surrounding the city that were also observed from other aircraft (Yokelson et al., 2007; DeCarlo et al., 2008). 

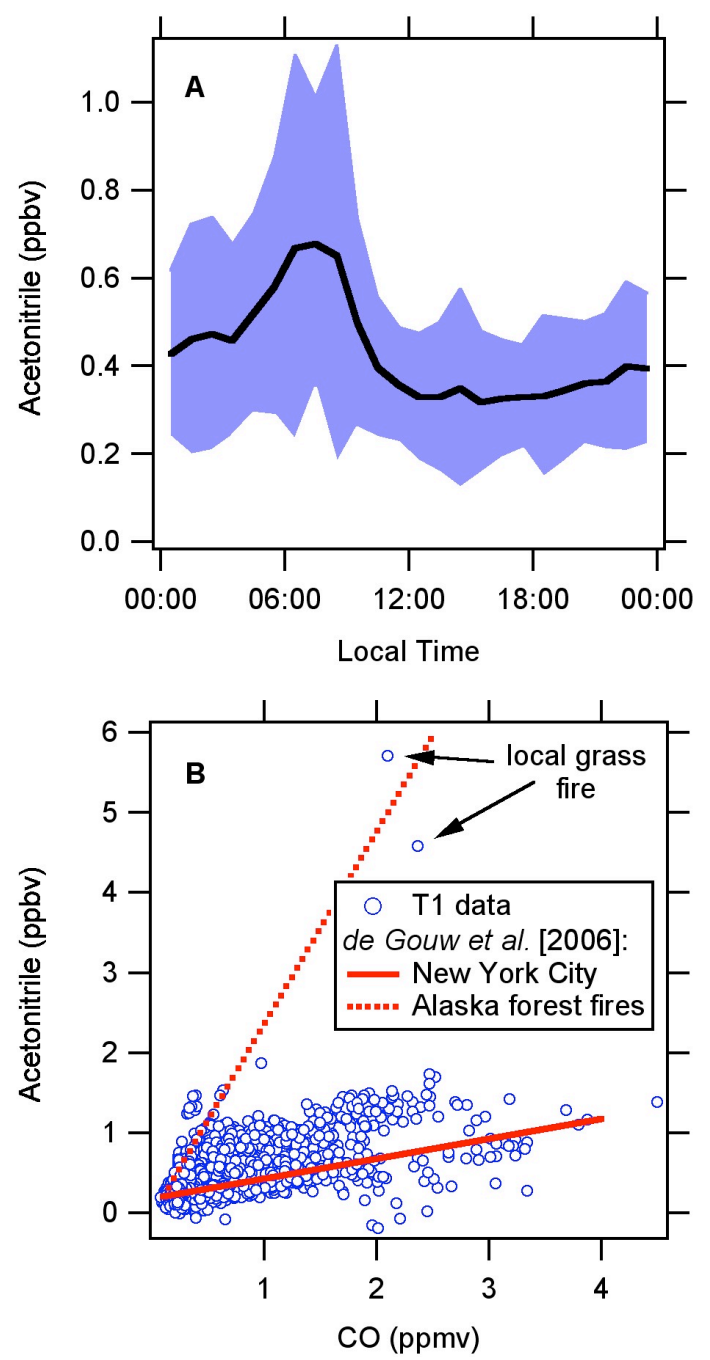

Fig. 8. (a) Diurnal variation of acetonitrile. The black line indicates the mean mixing ratio in hourly bins, and the blue area indicates the standard deviations in these hourly means. (b) Scatter plot of acetonitrile versus CO. The solid and dotted red lines indicate the ratios between acetonitrile and $\mathrm{CO}$ observed in plumes from New York City and forest fires in Alaska, respectively.

Levoglucosan is a tracer for biomass burning emissions in the particle phase and was measured from filter samples at the T1 site. Figure 9a shows a scatter plot of levoglucosan measured from the filter samples versus acetonitrile. The filters were collected over 24-h sampling times; the acetonitrile mixing ratios were averaged over these periods for the purpose of the comparison. It is seen that the two measurements correlate with an $r^{2}$ of 0.737 . The slope of a 2-sided regression fit to the data is $0.86 \mu \mathrm{g} \mathrm{m}^{-3} \mathrm{ppbv}^{-1}$. There is an offset in acetonitrile of $\sim 0.26 \mathrm{ppbv}$, which is explained by the long atmospheric lifetime of this compound: the background mixing ratio in the free troposphere varies typically between 0.1 and 0.2 ppbv (Warneke et al., 2006), i.e. somewhat lower than the offset in Fig. 9a.
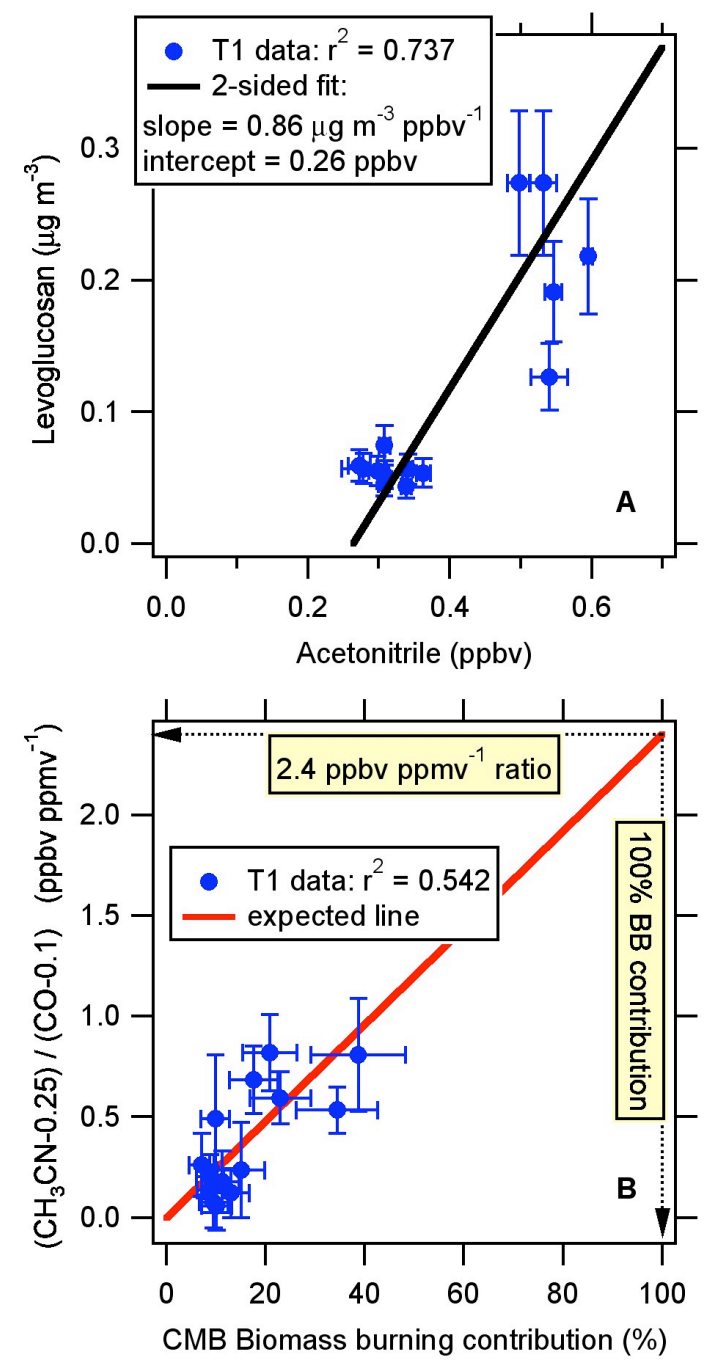

Fig. 9. (a) Scatter plot of levoglucosan versus acetonitrile. The error bars in levoglucosan reflect the uncertainty in the measurement. The error bars in acetonitrile reflect the error in the average over the 24-h filter sampling periods. (b) The average enhancement ratio of acetonitrile versus $\mathrm{CO}$ as a function of the biomass burning contribution to organic carbon aerosol determined from the Chemical Mass Balance (CMB) model (Stone et al., 2008).

As reported elsewhere, the biomass burning contribution to the organic carbon aerosol at $\mathrm{T} 1$ was determined from the data of levoglucosan and other molecular tracers using the chemical mass balance (CMB) model (Stone et al., 2008). The resulting percentage of organic carbon aerosol attributed to biomass burning varied between $7 \%$ and $39 \%$ at the $\mathrm{T} 1$ site. In Fig. $9 b$ the enhancement ratio of acetonitrile versus $\mathrm{CO}$ is plotted as a function of the biomass burning contribution from CMB. Since both acetonitrile and $\mathrm{CO}$ are long-lived trace gases, a background was subtracted from the ambient mixing ratios to determine the enhancement ratios. Here, we use $0.10 \pm 0.05$ ppmv for $\mathrm{CO}$, consistent 

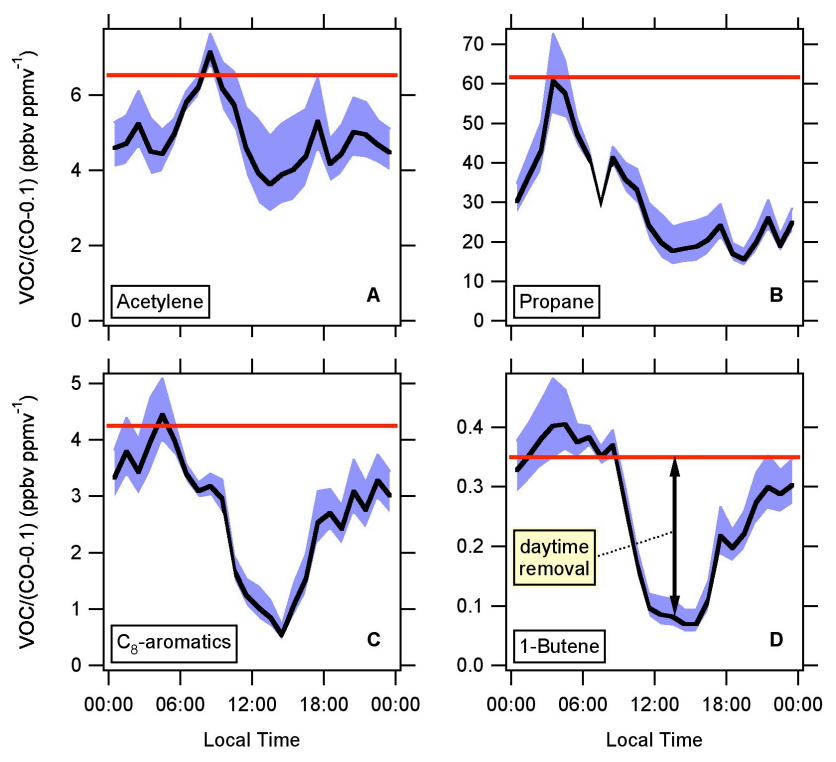

Fig. 10. Diurnal variations of the enhancement ratios versus $\mathrm{CO}$ of (a) acetylene, (b) propane, (c) the $\mathrm{C}_{8}$-aromatics and (d) 1-butene. The blue areas show the uncertainty due to a 0.05 -ppmv uncertainty in the assumed $\mathrm{CO}$ background of $0.1 \mathrm{ppmv}$. The red lines show the emission ratios determined elsewhere from this data set (Welsh-Bon et al., 2008).

with observations at the Picos Tres Padres and from the DOE G-1 aircraft (Herndon et al., 2008; Kleinman et al., 2008). For acetonitrile we use a background mixing ratio of $0.25 \pm 0.05 \mathrm{ppbv}$, which was derived from the intercepts of the best fits through the data in Fig. 8b and Fig. 9a, but is somewhat higher than observed elsewhere (0.1-0.2 ppbv) (Warneke et al., 2006). The error bars in Fig. 9b result from the uncertainties in the assumed backgrounds for $\mathrm{CO}$ and acetonitrile, respectively. The acetonitrile enhancement ratio correlates with the CMB biomass burning contribution $\left(r^{2}=0.542\right)$ and the data follow the expected trend represented by the red line in Fig. 9b: a zero enhancement of acetonitrile corresponds to a $0 \%$ biomass burning contribution, whereas an acetonitrile enhancement of $2.4 \mathrm{ppbv} \mathrm{ppmv}^{-1}$, as observed in forest fire plumes (de Gouw et al., 2003, 2006), corresponds to a $100 \%$ biomass burning contribution.

Emissions from forest fires were commonly observed in the vicinity of Mexico City (Yokelson et al., 2007; DeCarlo et al., 2008), but from the analysis presented in Figs. 8 and 9 , we conclude that biomass burning was not a dominant source of trace gases and aerosol at the T1 site during MILAGRO. It should be noted that the scatter plot of acetonitrile versus $\mathrm{CO}$ (Fig. 8b) is dominated by data from the early morning, when the surface was well isolated from the atmosphere aloft and mostly local emissions were sampled. Figure $8 \mathrm{~b}$ therefore suggests that the relative contribution of biomass burning emissions in Mexico City to the total may not be dissimilar from U.S. cities. On most days, the biomass

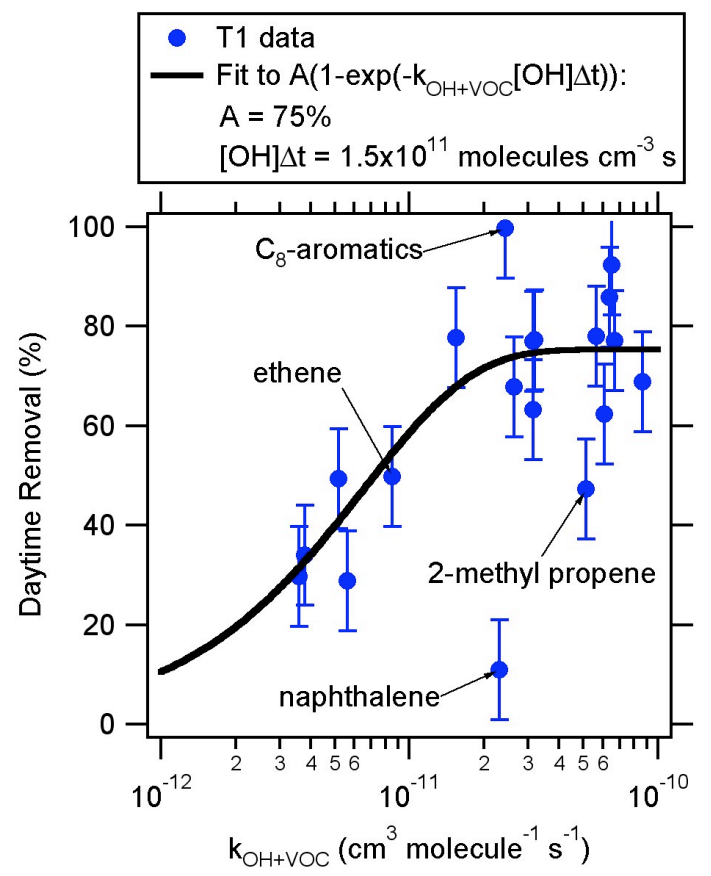

Fig. 11. Daytime removal of VOCs as a function of their reaction rate coefficient with $\mathrm{OH}$.

burning contribution to organic carbon aerosol was $30 \%$ or less (Fig. 9b), and we will not explicitly take this source into account in the remainder of the analysis. Several authors have pointed out that the period after 23 March 2006, had a lower impact of regional fires than the period before (Fast et al., 2007; Stone et al., 2008; Aiken et al., 2009). We repeated the analyses presented in Figs. 4 and 7 just for the period after 23 March and, within the uncertainties, found the same diurnal variations and emission ratios for the different aerosol species.

\subsection{Daytime removal of volatile organic compounds}

The diurnal variations of trace gases and aerosol shown in Figs. 3 and 4 are caused by diurnal variations in the emissions, chemistry and boundary-layer height. To account for the effect of emissions and boundary-layer height, one can normalize the observations to the mixing ratio of an inert trace gas, in this case $\mathrm{CO}$; in other words one can look at the enhancement ratios. Figure 10, shows the diurnal variations of the enhancement ratios of acetylene, propane, the $\mathrm{C}_{8}$-aromatics and 1-butene versus $\mathrm{CO}$. CO has a long lifetime and a background mixing ratio of $0.1 \mathrm{ppmv}$ is subtracted prior to the normalization; the blue shaded areas in Fig. 10 show the uncertainty introduced by a 0.05 -ppmv uncertainty in this assumed background. This uncertainty is higher in the afternoon when $\mathrm{CO}$ is lower (Fig. 3a). Background mixing ratios of VOCs are ignored in this analysis, as they tend to be small in comparison with the ambient mixing ratios. 
Figure 10 shows that the enhancement ratios of the $\mathrm{C}_{8}$ aromatics and 1-butene were the highest during the night and early morning, and similar to the emission ratios (red lines in Fig. 10) determined above from the scatter plots versus CO (Fig. 6) (Welsh-Bon et al., 2008). During the afternoon, the enhancement ratios of the $\mathrm{C}_{8}$-aromatics and 1butene showed a large decrease due to chemical removal by $\mathrm{OH}$. This decrease was smaller for a relatively inert compound such as acetylene (Fig. 10a). For most hydrocarbons, the diurnal variation in the enhancement ratios looked like acetylene or 1-butene, depending on their reactivity with $\mathrm{OH}$. The only exceptions were propane and the butanes, for which the enhancement ratios peaked much earlier during the night (Fig. 10b). However, the small alkanes were essentially not correlated with $\mathrm{CO}$, and their enhancement ratios versus $\mathrm{CO}$ are not very meaningful parameters.

We quantified the daytime removal for all hydrocarbon species by expressing the mid-afternoon reduction in the enhancement ratio as a percentage of the emission ratio (as shown in Fig. 10d). Figure 11 shows the daytime removal for all species as a function of their rate coefficient for the reaction with $\mathrm{OH}$. It is seen that the faster the reaction with $\mathrm{OH}$, the higher the daytime removal. One notable exception is naphthalene, which is very reactive but showed hardly any diurnal variation in its enhancement ratio. The explanation may be that this compound was not properly measured by PIT-MS: to date the measurement of that species has not been inter-compared to other methods, and there may be interference from other species to the signal at $129 \mathrm{amu}$.

As a result of the removal by $\mathrm{OH}$, the ratio between a VOC and $\mathrm{CO}$ depends on the time since emission $(\Delta t)$ as:

$$
\left.\frac{[\mathrm{VOC}]}{[\mathrm{CO}]}\right|_{t=\Delta t}=\left.\frac{[\mathrm{VOC}]}{[\mathrm{CO}]}\right|_{t=0} \exp \left(-\left(k_{\mathrm{OH}+\mathrm{VOC}}-k_{\mathrm{OH}+\mathrm{CO}}\right)[\mathrm{OH}] \Delta t\right),
$$

where $[\mathrm{VOC}] /\left.[\mathrm{CO}]\right|_{t=0}$ is the VOC emission ratio, $k_{\mathrm{OH}+\mathrm{VOC}}$ and $k_{\mathrm{OH}+\mathrm{CO}}$ are the rate coefficients for the $\mathrm{OH}$ reactions of the $\mathrm{VOC}$ and $\mathrm{CO}$, and $[\mathrm{OH}]$ is the concentration of $\mathrm{OH}$. The removal of a VOC can be calculated from Eq. (1) as:

$$
\begin{aligned}
& \text { Removal }=1-\frac{[\mathrm{VOC}] /\left.[\mathrm{CO}]\right|_{t=\Delta t}}{[\mathrm{VOC}] /\left.[\mathrm{CO}]\right|_{t=0}} \\
& =1-\exp \left(-\left(k_{\mathrm{OH}}+\mathrm{VOC}-k_{\mathrm{OH}+\mathrm{CO}}\right)[\mathrm{OH}] \Delta t\right) .
\end{aligned}
$$

For all species in Fig. 11, $k_{\mathrm{OH}+\mathrm{VOC}}$ is much larger than $k_{\mathrm{OH}+\mathrm{CO}}$ and the latter can be ignored. In addition, Fig. 11 shows that for the most reactive species, the removal does not go to $100 \%$. For these 2 reasons, the data in Fig. 11 (with the exception of the data point for naphthalene) are fit by the equation:

Removal $=A \times\left(1-\exp \left(-k_{\mathrm{OH}+\mathrm{VOC}}[\mathrm{OH}] \Delta t\right)\right)$,

the result of which is shown by the black curve. Equation (2) assumes that there are no continued emissions of VOCs into an air mass after $\Delta t=0$, which is an obvious simplification. Parameter A was found to be $(75 \pm 10) \%$ from the fit, suggesting that in the mid afternoon $(25 \pm 10) \%$
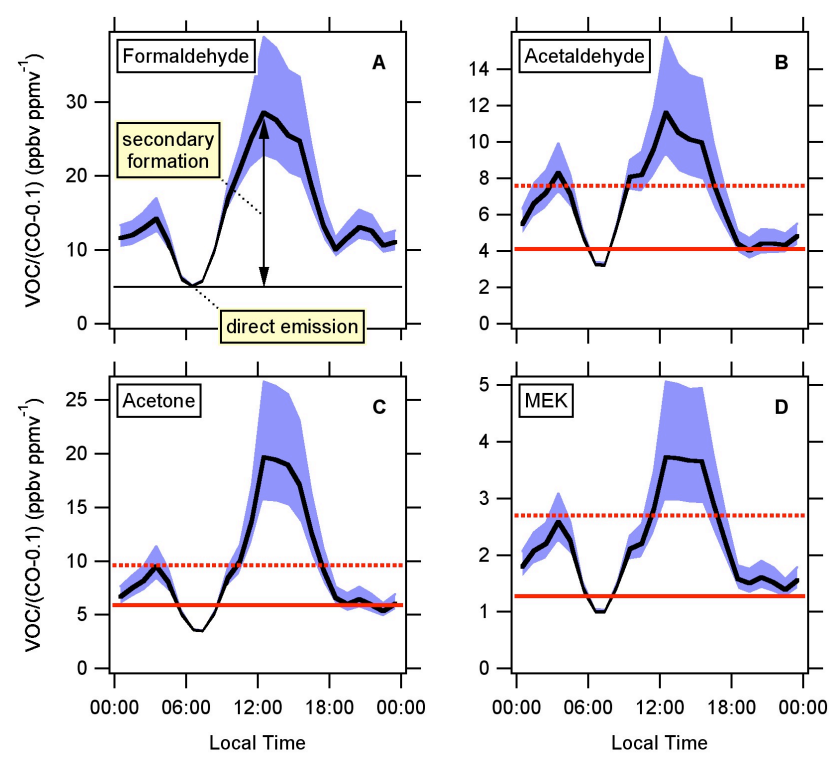

Fig. 12. Diurnal variations of the enhancement ratios versus $C O$ of (a) formaldehyde, (b) acetaldehyde, (c) acetone and (d) methyl ethyl ketone (MEK). The blue areas show the uncertainty due to a 0.05-ppmv uncertainty in the assumed CO background of $0.1 \mathrm{ppmv}$. The solid, red lines show the U.S. emission ratios (de Gouw et al., 2005) for acetaldehyde, acetone and MEK, and the dotted, red lines show the enhancement ratios observed in the U.S. for those species after $8 \mathrm{~h}$ of processing (Sommariva et al., 2008).

of the sampled air consisted of local non-processed emissions, whereas $(75 \pm 10) \%$ consisted of processed emissions that were released early in the day. The parameter $[\mathrm{OH}] \Delta t$ was found to be $(1.5 \pm 0.4) \times 10^{11}$ molecules $\mathrm{cm}^{-3} \mathrm{~s}$ from the fit. $\mathrm{OH}$ measurements at the $\mathrm{T} 1$ site by Huey and co-workers gave a daytime maximum concentration of $(5 \pm 2) \times 10^{6}$ molecules $\mathrm{cm}^{-3}$, in close agreement with results from a previous mission (Shirley et al., 2006). Taking this $\mathrm{OH}$ concentration, an $[\mathrm{OH}] \Delta t$ of $(1.5 \pm 0.4) \times 10^{11}$ molecules $\mathrm{cm}^{-3} \mathrm{~s}$ corresponds to a processing time of $8 \pm 4 \mathrm{~h}$, which is approximately the time between the highest VOC mixing ratios in the early morning and the lowest in the early afternoon (Fig. 3). This analysis shows that the removal of the primary hydrocarbons was largely consistent with $\mathrm{OH}$ chemistry. For ethene, the daytime removal was about $50 \%$ (Fig. 3), which means that there were still some fairly reactive species left in air masses transported away from $\mathrm{T} 1$ during the daytime. The lesser reactive species in Fig. 11 include the pentanes, n-hexane and toluene; not included were the butanes, propane and acetylene, in which cases the daytime removal was not meaningful or poorly defined by the data (Fig. 10). The more reactive species in Fig. 3 include the alkenes and aromatics; the daytime removal of the $\mathrm{C}_{8}$-aromatics, 2-methyl propene and naphthalene were not as well described by the best fit of Eq. (3). 


\subsection{Daytime formation of oxygenated VOCs and or- ganic aerosol}

Figure 12 shows the diurnal variations in the enhancement ratios of four oxygenated VOCs that have secondary sources in addition to direct emissions. The diurnal variations are very different from the hydrocarbons in Fig. 10, with the lowest enhancement ratios in the early morning, when primary emissions dominate the air mass composition, and much higher values in the afternoon due to secondary formation. There is also a second, smaller peak in the enhancement ratio around 03:00 a.m. This second smaller peak arises because $\mathrm{CO}$ was relatively constant during the night and rises very sharply at 05:00 a.m. (Fig. 3a), whereas acetaldehyde and acetone increased more gradually during the night (Fig. 3h and 3i). The data are overlaid with the emission ratios for direct urban emissions derived for the U.S. (red solid lines) (de Gouw et al., 2005), and the enhancement ratios observed in the U.S. after $8 \mathrm{~h}$ of processing (red dotted lines) (Sommariva et al., 2008). It is seen that the estimated U.S. emission ratios agree quite well with the enhancement ratios in the early morning when primary emissions dominate. The afternoon enhancement ratios are higher at $\mathrm{T} 1$ than observed in the U.S., which is expected since the emission ratios of most of their precursors are also higher. The uncertainties in the enhancement ratios are high, however, and the differences may not be significant for acetaldehyde and MEK. The difference is larger for acetone: the main acetone precursors are propane, iso-butane and iso-pentane (Jacob et al., 2002; Sommariva et al., 2008) and these were much higher in Mexico City than in the U.S. (Fig. 6b).

Figure 13 shows enhancement ratios of the different carbonaceous aerosol species versus $\mathrm{CO}$ measured at $\mathrm{T} 1$. The enhancement ratio of EC was relatively constant during the day and equal to the emission ratio derived earlier from the scatter plot in Fig. 7. This suggests that emissions of EC (Diesel vehicles) and CO (gasoline vehicles) have similar diurnal emission profiles. The enhancement ratio of HOA varied by a factor of 2 during the day, was lower in the morning when primary emissions were high, and higher in the afternoon. The red line in Fig. 13e represents the emission ratio determined from the scatter plot in Fig. 7a. This emission ratio is at the high end of the diurnal variation and in agreement with emission ratios derived from several other studies (Lanz et al., 2006; Takegawa et al., 2006; de Gouw et al., 2008; Kleinman et al., 2008). The green line in Fig. 13e represents the emission ratio from a study in Pittsburgh (Zhang et al., 2005b), which agrees better with the enhancement ratio found for HOA in the early morning. There is no clear explanation for the diurnal variation. It is possible that the high variability in HOA was due to the presence of trash burning in close proximity to the site or to an influence of biomass burning as discussed above.

The diurnal variations of the $\mathrm{OC}$, WSOC, OM and OOA enhancement ratios look very similar to those of the oxy- genated VOCs in Fig. 12, suggesting that secondary formation plays a significant role in the afternoon. Acetonitrile mixing ratios showed on average a minimum in the afternoon (Fig. 8a) and, therefore, it is unlikely that the increases in $\mathrm{OC}, \mathrm{OM}$ and $\mathrm{WSOC}$ in the afternoon can be explained by an increased contribution from biomass burning. Also, as mentioned before, the period after March 23, 2006, had a smaller impact from regional fires (Fast et al., 2007; Stone et al., 2008; Aiken et al., 2009). We repeated the analysis shown in Fig. 13 using the data after 23 March only and obtained the same results within the uncertainties. The data in Fig. 13 are overlaid with previous estimates of the direct emissions (red solid line) and secondary formation after 0.5 day of processing (red dotted line) in urban plumes in the U.S. (de Gouw et al., 2008). It is seen that the U.S. emission ratios agree well with the enhancement ratios of OC and $\mathrm{OM}$ in the early morning. In this analysis, the OC data are used as reported. If there were an offset in the OC data of $2 \mu \mathrm{gC} \mathrm{m}^{-3}$, then the enhancement ratio would be smaller throughout the day (black dashed curve in Fig. 13b), and would actually agree better with the results obtained in the U.S. The enhancement ratio for WSOC was not zero in the early morning. Direct emissions of WSOC from vehicles are negligible (Huang and Yu, 2007; Weber et al., 2007), but air masses with a zero contribution of processed emissions are rarely, if ever, found and the same is true for T1 where WSOC and OOA were quite high even in the early morning (Fig. 4). As acetonitrile showed the highest mixing ratios in the early morning (Fig. 8a), part of the WSOC may also be attributable to biomass burning as suggested elsewhere (Stone et al., 2008).

For OC, WSOC and OM, the enhancement ratios in the afternoon agreed very well with observations in urban plumes in the U.S. after 0.5 day of processing (red dotted lines in Fig. 13). The corrected curve for OC (black dashed curve in Fig. 13b), assuming an offset of $2 \mu \mathrm{gC} \mathrm{m}^{-3}$ in the measurement, agrees better with the U.S. results. One might expect to see more formation of secondary organic aerosol since the emission ratios of the aromatic VOCs, an important class of precursors, are higher in Mexico City than in the U.S. This difference is not clear from the present analysis; a similar conclusion was drawn from airborne measurements in the outflow from Mexico City (DeCarlo et al., 2008; Kleinman et al., 2008).

\subsection{Budget of total observed organic carbon}

The measurements of organic carbon in the gas and aerosol phases can now be combined to address the budget of total observed organic carbon (TOOC), a concept recently introduced by Heald et al. (2008). All of the measurements of gas-phase compounds were converted to carbon mass loadings and the results are summarized in Table 2 and in Fig. 14. Included in this analysis are measurements of several alkane species measured from the canisters (see Table 1); 

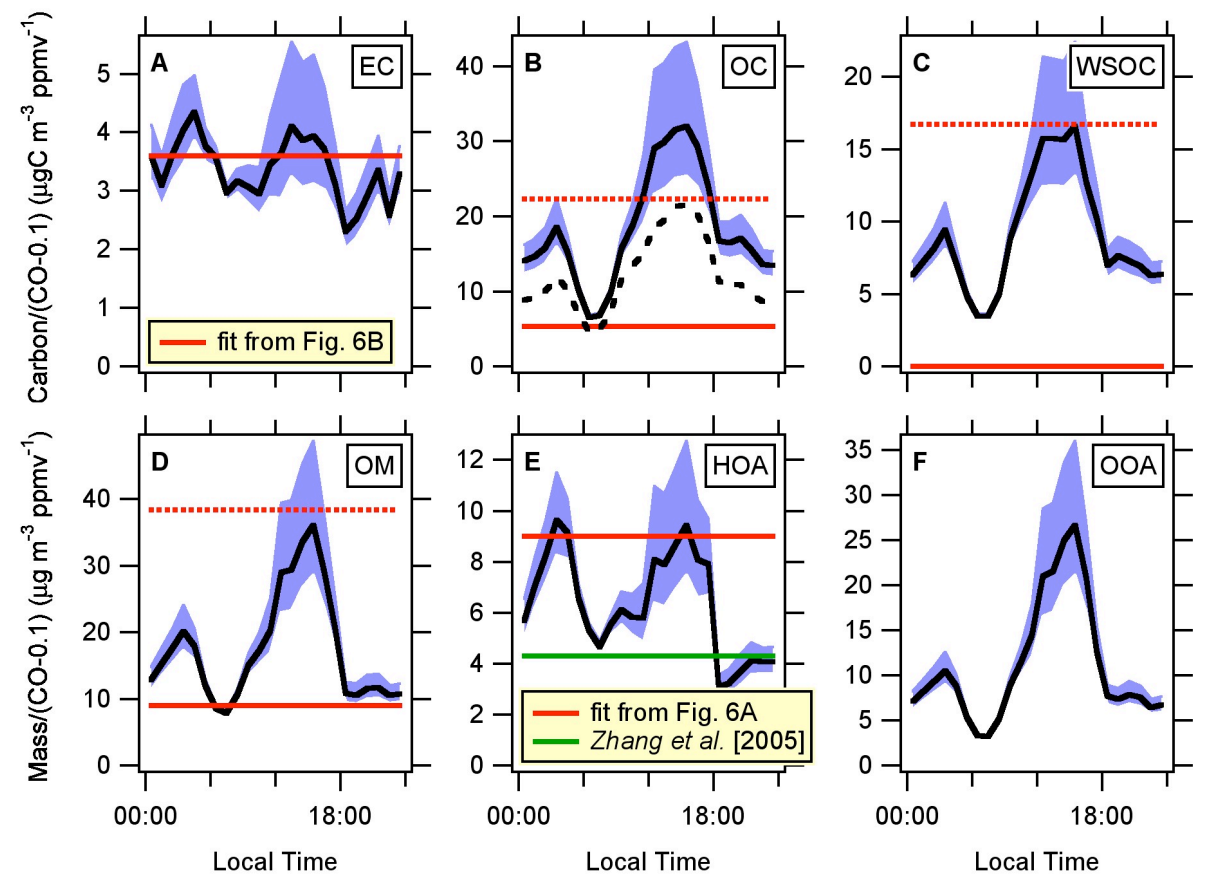

Fig. 13. Diurnal variations of the enhancement ratios of different aerosol species versus CO. The blue shaded areas show the uncertainty due to a 0.05 -ppmv uncertainty in the assumed $\mathrm{CO}$ background of $0.1 \mathrm{ppmv}$. The red lines indicate estimates for the direct emissions (solid) and secondary formation after half a day of processing (dotted) of organic aerosol in the northeastern U.S. (de Gouw et al., 2008). The black dashed line in panel (b) indicates the diurnal variation assuming an offset of $2 \mu \mathrm{gC} \mathrm{m}^{-3}$ in the OC measurement.

the time resolution of these data was insufficient to construct diurnal profiles but they are used here to contrast the early morning and afternoon data. The TOOC in Table 2 and Fig. 14 includes measurements of most of the important alkanes, alkenes and aromatics, but only a limited list of oxygenated VOCs (formaldehyde, methanol, acetaldehyde, acetone, acetic acid and MEK) (Table 1). PAN compounds and organic nitrates were not included in the analysis, but are expected to constitute a minor fraction of TOOC (de Gouw et al., 2005). Also not included are biogenic VOCs, which were small at $\mathrm{T} 1$. Isoprene was determined from the canister measurements only, had a mean mixing ratio of $60 \mathrm{pptv}$ and a maximum of 340 pptv; monoterpenes were not reported from the measurements at T1. The OC data in Table 2 and Fig. 14 are used as reported. If there were an offset in the OC measurement of $2 \mu \mathrm{gC} \mathrm{m}^{-3}$, then the average mass loadings in Table 2 would be reduced accordingly, and the fraction of OC to the total would be reduced from $3.7 \%$ to $2.7 \%$ in the morning and from $16.9 \%$ to $11.8 \%$ in the afternoon.

Obviously the concentrations of trace gases and aerosol at $\mathrm{T} 1$ were highly variable (Figs. 3 and 4): for example, CO was $1.2 \pm 0.8$ ppmv from 06:00-08:00 a.m., and 0.29 $\pm 0.13 \mathrm{ppmv}$ from 12:00-04:00 p.m., where the errors indicate the $1-\sigma$ standard deviation in the observations. However, the relative contribution from each species was much more constant (Fig. 6). The errors in Table 2 reflect the uncertainties in the relative contributions from each class, i.e. the errors from scatter plots of the VOCs and OC versus CO (Welsh-Bon et al., 2008).

In the early morning, TOOC was $192 \mu \mathrm{gC} \mathrm{m}^{-3}$ and consisted largely of gas-phase species. Among those, the largest contributions came from alkanes and aromatics. In the afternoon, TOOC was reduced to $35 \mu \mathrm{gC} \mathrm{m}^{-3}$ and the composition was very different. Although the largest contribution still came from alkanes, the oxygenated VOCs and organic aerosol were now almost $50 \%$ of the total. These compositional changes are qualitatively similar to what has been observed in the northeastern U.S. (for example, see Fig. 14c in de Gouw et al., 2005), with the exception of a larger role for alkanes in Mexico City. TOOC at T1 was lower than the average TOOC observed at the urban site T0 during MILAGRO (316 $\mu \mathrm{gC} \mathrm{m}^{-3}$ (Heald et al., 2008); converted from STP to ambient conditions using a factor of 1.44). This gradient between $\mathrm{T} 0$ and $\mathrm{T} 1$ was observed in many of the chemical measurements (Kleinman et al., 2008; Stone et al., 2008). The daytime TOOC at $\mathrm{T} 1$ was higher than the average TOOC observed from the $\mathrm{C}-130$ research aircraft during MILAGRO $\left(11.7 \mu \mathrm{gC} \mathrm{m}^{-3}\right.$; converted from STP to ambient conditions using a factor of 1.44), although TOOC concentrations up to $35 \mu \mathrm{gC} \mathrm{m}^{-3}$ were observed during daytime flights in the Mexico City basin (Heald et al., 2008).

The decrease in TOOC from $192 \mu \mathrm{gC} \mathrm{m}^{-3}$ in the early morning to $35 \mu \mathrm{gC} \mathrm{m}^{-3}$ in the mid afternoon can be mostly attributed to dilution in the expanding boundary layer. First, 


$$
\begin{aligned}
& \text { 6-8 am Local Time: } \\
& \mathrm{T}=5^{\circ} \mathrm{C} \\
& \mathrm{CO}=1.2 \pm 0.8 \mathrm{ppmv} \\
& \text { TOOC }=192 \mu \mathrm{gC} \mathrm{m}{ }^{-3}
\end{aligned}
$$

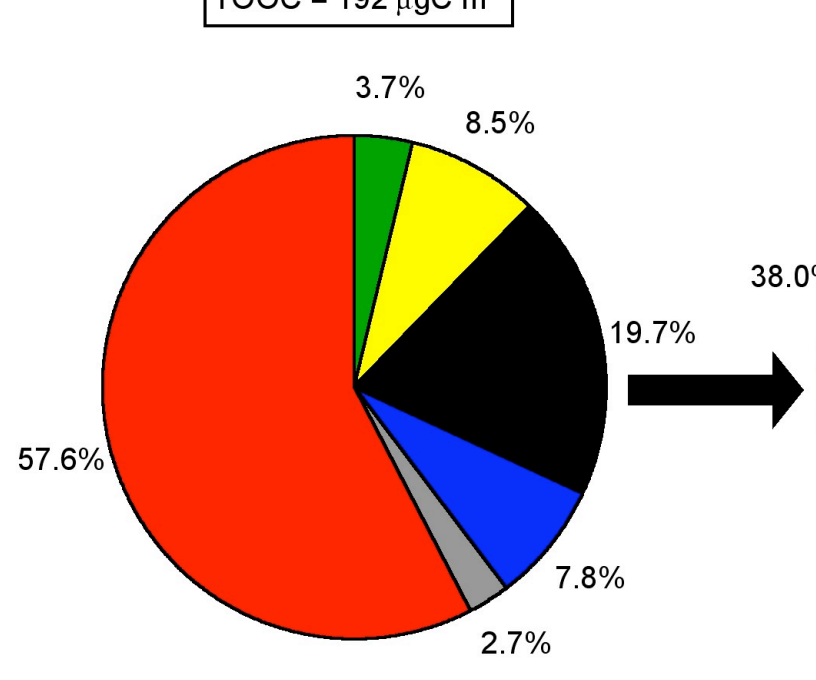

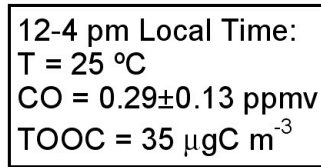

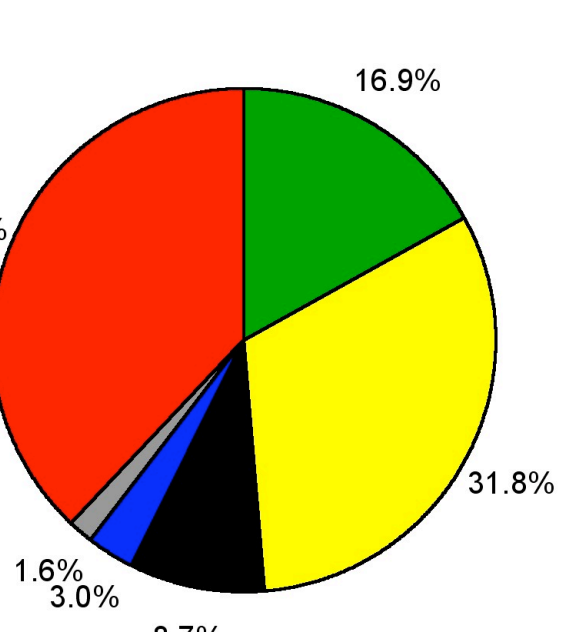

$8.7 \%$

\begin{tabular}{|llll|}
\hline$\square$ Alkanes & $\square$ & Aromatics \\
$\square$ & Acetylene & $\square$ & Oxygenates \\
$\square$ & Alkenes & $\square$ & OC \\
\hline
\end{tabular}

Fig. 14. Budget of total observed organic carbon (TOOC), i.e. the observed organic carbon in the combined gas and aerosol phases.

Table 2. Average composition of total observed organic carbon (TOOC) at T1 in the early morning and mid afternoon. The species added for each class are given in Table 1.

\begin{tabular}{|c|c|c|c|c|}
\hline \multirow[t]{2}{*}{$\begin{array}{l}\text { Compound } \\
\text { Class }\end{array}$} & \multicolumn{2}{|c|}{$\begin{array}{l}\text { Organic Carbon } \\
\left(\mu \mathrm{gC} \mathrm{m}{ }^{-3}\right)\end{array}$} & \multicolumn{2}{|c|}{$\begin{array}{l}\text { Organic Carbon / (CO-0.1 ppmv) } \\
\left(\mu \mathrm{gC} \mathrm{m}^{-3} \mathrm{ppmv}^{-1}\right)\end{array}$} \\
\hline & 06:00-08:00 a.m. LT & 12:00-04:00 p.m. LT & 06:00-08:00 a.m. LT & 12:00-04:00 p.m. LT \\
\hline \multicolumn{5}{|c|}{ Gas Phase } \\
\hline Alkanes & $110 \pm 13$ & $13 \pm 3$ & $103 \pm 13$ & $70 \pm 20$ \\
\hline Acetylene & $5.2 \pm 0.3$ & $0.57 \pm 0.06$ & $4.9 \pm 0.3$ & $2.9 \pm 0.8$ \\
\hline Alkenes & $15.0 \pm 0.4$ & $1.06 \pm 0.06$ & $14.0 \pm 0.8$ & $5.5 \pm 1.5$ \\
\hline Aromatics & $38 \pm 3$ & $3.0 \pm 0.4$ & $35 \pm 3$ & $16 \pm 5$ \\
\hline Oxygenates & $16 \pm 2$ & $11 \pm 3$ & $15 \pm 2$ & $60 \pm 20$ \\
\hline \multicolumn{5}{|c|}{ Aerosol Phase } \\
\hline $\mathrm{OC}$ & $7.1 \pm 1.1$ & $6 \pm 2$ & $6.7 \pm 1.0$ & $31 \pm 12$ \\
\hline \multicolumn{5}{|c|}{ Combined } \\
\hline TOOC & $192 \pm 13$ & $35 \pm 4$ & $179 \pm 15$ & $180 \pm 50$ \\
\hline
\end{tabular}

the average depth of the boundary layer increased from around $500 \mathrm{~m}$ at 09:00 a.m. to more than $3000 \mathrm{~m}$ at 05:00 p.m. (Shaw et al., 2007), i.e. an increase by a factor of $\sim 6$ that is similar to the decrease in TOOC by a factor of $\sim 5.5$. Second, the enhancement ratio of TOOC versus CO, calculated similarly to the ratios in Figs. 10, 12 and 13, was relatively constant at $179 \pm 15 \mu \mathrm{gC} \mathrm{m}^{-3} \mathrm{ppmv}^{-1}$ in the early morning and $180 \pm 50 \mu \mathrm{gC} \mathrm{m}^{-3} \mathrm{ppmv}^{-1}$ in the mid afternoon (Table 2). The error bars in these enhancement ratios are determined (i) by the 0.05 -ppmv uncertainty in the assumed $\mathrm{CO}$ background of $0.1 \mathrm{ppmv}$ and (ii) by the uncertainties in the composition discussed above. A possible offset in the OC measurement would not affect this result significantly. During a previous experiment, a decrease in TOOC of $40 \%$ 
was observed in polluted air over the course of 2 days of processing (de Gouw et al., 2005). The uncertainties in these analyses are large, however: in the present study we can only say that TOOC is conserved within $\pm 30 \%$ and the decrease in TOOC in our previous study must have had a similar, if not larger, error bar.

\subsection{Implications for secondary organic aerosol forma- tion}

How do these observations further our understanding of SOA formation? First, the results confirm that SOA increases strongly in urban air and is typically much higher than primary organic aerosol (POA) in the afternoon. Also, even though it is not explicitly shown here, this growth of SOA is very difficult to explain in terms of the measured precursors and their particulate mass yields. Evidence for this can be found in Table 2: the enhancement ratio of all aromatic species combined decreases from 35 to $16 \mu \mathrm{gC} \mathrm{m}^{-3} \mathrm{ppmv}^{-1}$ during the day, whereas OC increases from 7 to $31 \mu \mathrm{gC} \mathrm{m}^{-3} \mathrm{ppmv}^{-1}$ (from 5 to $20 \mu \mathrm{gC} \mathrm{m}^{-3} \mathrm{ppmv}^{-1}$ if there were an offset in the OC measurements). Aromatic VOCs are typically assumed to be the most important anthropogenic precursors of SOA (Volkamer et al., 2006; de Gouw et al., 2008), but one would have to assume a particulate mass yield close to or over $100 \%$ to explain these observations, whereas recent laboratory data indicate yields in the 10-30\% range for most aromatics depending on $\mathrm{NO}_{\mathrm{x}}$ levels (Ng et al., 2007). The combination of these observations implies that the formation of SOA is under-predicted by as much as an order of magnitude, a finding that is similar to observations in the U.S. and Mexico City (de Gouw et al., 2005; Volkamer et al., 2006; de Gouw et al., 2008; Kleinman et al., 2008).

As reported in this study and also from the G-1 aircraft data (Kleinman et al., 2008), the enhancement ratio of SOA relative to $\mathrm{CO}$ is quantitatively very similar to our previous observations of SOA formation in the northeastern U.S. (de Gouw et al., 2005; de Gouw et al., 2008). This may come as a surprise, since (1) the emission ratios of aromatic precursors are reported to be higher in Mexico City than in the U.S. (Welsh-Bon et al., 2008), and (2) biogenic VOCs play a much less important role in Mexico City than in the U.S. There may be two explanations for the similarity between Mexico City and the northeastern U.S. First, it is possible that the effects of enhanced aromatics and reduced biogenics cancel and give the same formation of SOA versus $\mathrm{CO}$ in either environment. Second, it is possible that aromatics and biogenics are not the dominant precursors of SOA in either environment, with a larger role for semi-volatiles (Robinson et al., 2007). In that regard, it is important to note that direct emissions of HOA relative to $\mathrm{CO}$, and therefore perhaps of semi-volatiles, were the same in Mexico City and the northeastern U.S.

\section{Conclusions}

We measured volatile organic compounds (VOCs) and carbonaceous aerosol at T1 during MILAGRO. Diurnal variations of hydrocarbons, elemental carbon (EC) and hydrocarbon-like organic aerosol (HOA) were dominated by a high peak in the early morning when local emissions accumulated in a shallow boundary layer, and a minimum in the afternoon when the emissions were diluted in a significantly expanded boundary layer, and were removed by $\mathrm{OH}$ in case of the reactive gases. In comparison, diurnal variations of species with secondary sources such as the aldehydes, ketones and organic aerosol stayed relatively high in the afternoon indicating strong photochemical formation.

From scatter plots of hydrocarbons versus CO, the emission ratios were determined and for most species these were higher in Mexico City than in the U.S. The removal of hydrocarbons during the day was investigated and could be largely explained from their reaction with $\mathrm{OH}$. Emission ratios of oxygenated VOCs, EC and HOA were in reasonable agreement with observations in the U.S., although the degree of correlation between HOA and $\mathrm{CO}$ was not as high as observed elsewhere, possibly caused by additional sources of HOA such as biomass and trash burning.

Secondary formation of oxygenated VOCs and organic aerosol was investigated and compared with observations in the U.S. Secondary formation of acetone may be more efficient in Mexico City, possibly due to higher emissions of alkane precursors from the use of liquefied petroleum gas. Secondary formation of organic aerosol was similar between Mexico City and the U.S.

Combining the data for all measured gas and aerosol species, we described the budget of total observed organic carbon (TOOC), and find that the enhancement ratio of TOOC relative to $\mathrm{CO}$ is conserved between the early morning and mid afternoon despite large compositional changes: hydrocarbons dominated in the early morning, whereas organic aerosol and oxygenated VOCs accounted for almost $50 \%$ of the organic carbon in the mid afternoon. The implications of these findings regarding the formation of secondary organic aerosol (SOA) were discussed. Despite higher emission ratios of aromatic hydrocarbons versus $\mathrm{CO}$ in Mexico City, we did not see higher SOA formation. On the other hand, a much lower contribution of biogenic VOCs in Mexico City did not lead to a reduced SOA formation in comparison with observations in the U.S.

Finally, the influence of biomass burning was investigated using the measurements of acetonitrile. Acetonitrile in the gas phase correlated well with levoglucosan in the particle phase. The diurnal variation of acetonitrile showed a strong maximum in the early morning, indicating a contribution from local burning sources. Scatter plots of acetonitrile versus CO suggested that the contribution of biomass burning was not dominant and perhaps not dissimilar from observations in the U.S. Work is in progress to quantify the relative 
importance of biomass burning and anthropogenic sources of organic aerosol to the air masses sampled at $\mathrm{T} 1$.

Acknowledgements. This work was financially supported by the National Science Foundation under grant number ATM-0516610. We thank James Schauer and Elizabeth Stone for the use of their levoglucosan data, and Jose Jimenez for careful reading of the manuscript and many useful comments.

Edited by: L. Molina

\section{References}

Aiken, A. C., Salcedo, D., Cubison, M. J., et al.: Mexico City aerosol analysis during MILAGRO using high resolution aerosol mass spectrometry at the urban supersite (T0) - Part 1: Fine particle composition and organic source apportionment, Atmos. Chem. Phys. Discuss., 9, 8377-8427, 2009,

http://www.atmos-chem-phys-discuss.net/9/8377/2009/.

Atkinson, R. and Arey, J.: Atmospheric degradation of volatile organic compounds, Chem. Rev., 103, 4605-4638, 2003.

Baker, A. K., Beyersdorf, A. J., Doezema, L. A., Katzenstein, A., Meinardi, S., Simpson, I. J., Blake, D. R., and Rowland, F. S.: Measurements of nonmethane hydrocarbons in 28 United States cities, Atmos. Environ., 42, 170-182, 2008.

Ban-Weiss, G. A., McLaughlin, J. P., Harley, R. A., Lunden, M. M., Kirchstetter, T. W., Kean, A. J., Strawa, A. W., Stevenson, E. D., and Kendall, G. R.: Long-term changes in emissions of nitrogen oxides and particulate matter from on-road gasoline and diesel vehicles, Atmos. Environ., 42, 220-232, 2008.

Baumgardner, D., Raga, G., Peralta, O., Rosas, I., Castro, T., Kuhlbusch, T., John, A., and Petzold, A.: Diagnosing black carbon trends in large urban areas using carbon monoxide measurements, J. Geophys. Res.-Atmos., 107, 8342, doi:10.1029/2001JD000626, 2002.

Blake, D. R. and Rowland, F. S.: Urban Leakage of Liquefied Petroleum Gas and Its Impact on Mexico-City Air-Quality, Science, 269, 953-956, 1995.

Canagaratna, M. R., Jayne, J. T., Jimenez, J. L., et al.: Chemical and microphysical characterization of ambient aerosols with the aerodyne aerosol mass spectrometer, Mass Spectro. Rev., 26, 185-222, 2007.

de Gouw, J. A., Brock, C. A., Atlas, E. L., et al.: Sources of particulate matter in the northeastern United States: 1. Direct emissions and secondary formation of organic matter in urban plumes, J. Geophys. Res.-Atmos., 113, D08301, doi:10.1029/2007JD009243, 2008.

de Gouw, J. A., Middlebrook, A. M., Warneke, C., et al.: Budget of organic carbon in a polluted atmosphere: Results from the New England Air Quality Study in 2002, J. Geophys. Res.-Atmos., 110, D16305, doi:10.1029/2004JD005623, 2005.

de Gouw, J. A. and Warneke, C.: Measurements of volatile organic compounds in the Earth's atmosphere using proton-transferreaction mass spectrometry, Mass Spectrom. Rev., 26, 223-257, 2007.

de Gouw, J. A., Warneke, C., Parrish, D. D., Holloway, J. S., Trainer, M., and Fehsenfeld, F. C.: Emission sources and ocean uptake of acetonitrile $(\mathrm{CH} 3 \mathrm{CN})$ in the atmosphere, J. Geophys. Res.-Atmos., 108, 4329, doi:10.1029/2002JD002897, 2003. de Gouw, J. A., Warneke, C., Stohl, A., et al.: Volatile organic compounds composition of merged and aged forest fire plumes from Alaska and western Canada, J. Geophys. Res.-Atmos., 111, D10303, doi:10.1029/2005JD006175, 2006.

DeCarlo, P. F., Dunlea, E. J., Kimmel, J. R., et al.: Fast airborne aerosol size and chemistry measurements above Mexico City and Central Mexico during the MILAGRO Campaign, Atmos. Chem. Phys., 8, 4027-4048, 2008, http://www.atmos-chem-phys.net/8/4027/2008/.

DeCarlo, P. F., Kimmel, J. R., Trimborn, A., et al.: Fielddeployable, high-resolution, time-of-flight aerosol mass spectrometer, Anal. Chem., 78, 8281-8289, 2006.

Docherty, K. S., Stone, E. A., Ulbrich, I. M., et al.: Apportionment of primary and secondary organic aerosols in Southern California during the 2005 Study of Organic Aerosols in Riverside (SOAR-1), Environ. Sci. Technol., 42, 7655-7662, doi:10.1021/es8008166, 2008.

Doran, J. C., Barnard, J. C., Arnott, W. P., et al.: The T1-T2 study: evolution of aerosol properties downwind of Mexico City, Atmos. Chem. Phys., 7, 1585-1598, 2007, http://www.atmos-chem-phys.net/7/1585/2007/.

Drewnick, F., Hings, S. S., DeCarlo, P., et al.: A new time-of-flight aerosol mass spectrometer (TOF-AMS) - Instrument description and first field deployment, Aerosol Sci. Tech., 39, 637-658, 2005.

Eller, P. M. and Cassinelli, M. E.: NIOSH Manual of Analytical Methods, National Institute for Occupational Safety and Health, Cincinnati, 1996.

Ervens, B., Carlton, A. G., Turpin, B. J., Altieri, K. E., Kreidenweis, S. M., and Feingold, G.: Secondary organic aerosol yields from cloud-processing of isoprene oxidation products, Geophys. Res. Lett., 35, L02816, doi:10.1029/2007GL031828, 2008.

Fast, J. D., de Foy, B., Acevedo Rosas, F., et al.: A meteorological overview of the MILAGRO field campaigns, Atmos. Chem. Phys., 7, 2233-2257, 2007,

http://www.atmos-chem-phys.net/7/2233/2007/.

Fortner, E. C., Zheng, J., Zhang, R., Knighton, W. B., and Molina, L.: Measurements of volatile organic compounds using proton transfer reaction - mass spectrometry during the MILAGRO 2006 Campaign, Atmos. Chem. Phys., 9, 467-481, 2008, http://www.atmos-chem-phys.net/9/467/2008/.

Garcia, A. R., Volkamer, R., Molina, L. T., Molina, M. J., Samuelson, J., Mellqvist, J., Galle, B., Herndon, S. C., and Kolb, C. E.: Separation of emitted and photochemical formaldehyde in Mexico City using a statistical analysis and a new pair of gas-phase tracers, Atmos. Chem. Phys., 6, 4545-4557, 2006, http://www.atmos-chem-phys.net/6/4545/2006/.

Goldstein, A. H. and Galbally, I. E.: Known and unexplored organic constituents in the Earth's atmosphere, Environ. Sci. Technol., 41, 1514-1521, 2007.

Hak, C., Pundt, I., Kern, C., et al.: Intercomparison of four different in-situ techniques for ambient formaldehyde measurements in urban air, Atmos. Chem. Phys., 5, 2881-2900, 2005, http://www.atmos-chem-phys.net/5/2881/2005/.

Heald, C. L., Goldstein, A. H., Allan, J. D., et al.: Total observed organic carbon (TOOC) in the atmosphere: a synthesis of North American observations, Atmos. Chem. Phys., 8, 20072025, 2008, http://www.atmos-chem-phys.net/8/2007/2008/. 
Hennigan, C. J., Sullivan, A. P., Fountoukis, C. I., et al.: On the volatility and production mechanisms of newly formed nitrate and water soluble organic aerosol in Mexico City, Atmos. Chem. Phys., 8, 3761-3768, 2008,

http://www.atmos-chem-phys.net/8/3761/2008/.

Herndon, S. C., Onasch, T. B., Wood, E. C., et al.: Correlation of secondary organic aerosol with odd oxygen in Mexico City, Geophys. Res. Lett., 35, L15804, doi:10.1029/2008GL034058, 2008.

Holzinger, R., Jordan, A., Hansel, A., and Lindinger, W.: Automobile emissions of acetonitrile: Assessment of its contribution to the global source, J. Atmos. Chem., 38, 187-193, 2001.

Huang, X. F. and Yu, J. Z.: Is vehicle exhaust a significant primary source of oxalic acid in ambient aerosols?, Geophys. Res. Lett., 34, L02808, doi:10.1029/2006GL028457, 2007.

Jacob, D. J., Field, B. D., Jin, E. M., Bey, I., Li, Q. B., Logan, J. A., Yantosca, R. M., and Singh, H. B.: Atmospheric budget of acetone, J. Geophys. Res.-Atmos., 107, doi:10.1029/2001JD000694, 2002.

Johnson, K. S., Laskin, A., Jimenez, J. L., Shutthanandan, V., Molina, L. T., Salcedo, D., Dzepina, K., and Molina, M. J.: Comparative analysis of urban atmospheric aerosol by ProtonInduced X-ray Emission (PIXE), Proton Elastic Scattering Analysis (PESA), and Aerosol Mass Spectrometry (AMS), Environ. Sci. Technol., 42, 6619-6624, 2008.

Junkermann, W. and Burger, J. M.: A new portable instrument for continuous measurement of formaldehyde in ambient air, J. Atmos. Ocean. Tech., 23, 38-45, 2006.

Kirchstetter, T. W., Harley, R. A., Kreisberg, N. M., Stolzenburg, M. R., and Hering, S. V.: On-road measurement of fine particle and nitrogen oxide emissions from light- and heavy-duty motor vehicles, Atmos. Environ., 33, 2955-2968, 1999.

Kleinman, L. I., Springston, S. R., Daum, P. H., et al.: The time evolution of aerosol composition over the Mexico City plateau, Atmos. Chem. Phys., 8, 1559-1575, 2008, http://www.atmos-chem-phys.net/8/1559/2008/.

Kondo, Y., Miyazaki, Y., Takegawa, N., Miyakawa, T., Weber, R. J., Jimenez, J. L., Zhang, Q., and Worsnop, D. R.: Oxygenated and water-soluble organic aerosols in Tokyo, J. Geophys. Res.Atmos., 112, D01203, doi:10.1029/2006JD007056, 2007.

Kuster, W. C., Jobson, B. T., Karl, T., Riemer, D., Apel, E., Goldan, P. D., and Fehsenfeld, F. C.: Intercomparison of volatile organic carbon measurement techniques and data at la porte during the TexAQS2000 Air Quality Study, Environ. Sci. Technol., 38, 221228, 2004.

Lanz, V. A., Alfarra, M. R., Baltensperger, U., Buchmann, B., Hueglin, C., and Prevot, A. S. H.: Source apportionment of submicron organic aerosol at an urban site by linear unmixing of aerosol mass spectra, Atmos. Chem. Phys., 7, 1503-1522., 2006.

Lanz, V. A., Alfarra, M. R., Baltensperger, U., Buchmann, B., Hueglin, C., and Prevot, A. S. H.: Source apportionment of submicron organic aerosols at an urban site by factor analytical modelling of aerosol mass spectra, Atmos. Chem. Phys., 7, 15031522, 2007, http://www.atmos-chem-phys.net/7/1503/2007/.

Liu, L., Andreani-Aksoyoglu, S., Keller, J., et al.: A photochemical modeling study of ozone and formaldehyde generation and budget in the Po basin, J. Geophys. Res.-Atmos., 112, D22303, doi:10.1029/2006JD008172, 2007a.
Liu, P. S. K., Deng, R., Smith, K. A., et al.: Transmission efficiency of an aerodynamic focusing lens system: Comparison of model calculations and laboratory measurements for the Aerodyne Aerosol Mass Spectrometer, Aerosol Sci. Tech., 41, 721733, $2007 \mathrm{~b}$.

Moffet, R. C., de Foy, B., Molina, L. T., Molina, M. J., and Prather, K. A.: Measurement of ambient aerosols in northern Mexico City by single particle mass spectrometry, Atmos. Chem. Phys., 8 , 4499-4516, 2008, http://www.atmos-chem-phys.net/8/4499/2008/.

Ng, N. L., Kroll, J. H., Chan, A. W. H., Chhabra, P. S., Flagan, R. C., and Seinfeld, J. H.: Secondary organic aerosol formation from m-xylene, toluene, and benzene, Atmos. Chem. Phys., 7, 3909-3922, 2007, http://www.atmos-chem-phys.net/7/3909/2007/.

Offenberg, J. H., Lewandowski, M., Edney, E. O., Kleindienst, T. E., and Jaoui, M.: Investigation of a systematic offset in the measurement of organic carbon with a semicontinuous analyzer, J. Air Waste Manage., 57, 596-599, 2007.

Peltier, R. E., Weber, R. J., and Sullivan, A. P.: Investigating a liquid-based method for online organic carbon detection in atmospheric particles, Aerosol Sci. Tech., 41, 1117-1127, 2007.

Querol, X., Pey, J., Minguillón, M. C., et al.: PM speciation and sources in Mexico during the MILAGRO-2006 Campaign, Atmos. Chem. Phys., 8, 111-128, 2008, http://www.atmos-chem-phys.net/8/111/2008/.

Robinson, A. L., Donahue, N. M., Shrivastava, M. K., Weitkamp, E. A., Sage, A. M., Grieshop, A. P., Lane, T. E., Pierce, J. R., and Pandis, S. N.: Rethinking organic aerosols: semivolatile emissions and photochemical aging, Science, 315, 1259-1262, 2007.

Salcedo, D., Onasch, T. B., Dzepina, K., et al.: Characterization of ambient aerosols in Mexico City during the MCMA-2003 campaign with Aerosol Mass Spectrometry: results from the CENICA Supersite, Atmos. Chem. Phys., 6, 925-946, 2006, http://www.atmos-chem-phys.net/6/925/2006/.

Shaw, W. J., Pekour, M. S., Coulter, R. L., Martin, T. J., and Walters, J. T.: The daytime mixing layer observed by radiosonde, profiler, and lidar during MILAGRO, Atmos. Chem. Phys. Discuss., 7, 15 025-15 065, 2007, http://www.atmos-chem-phys-discuss.net/7/15025/2007/.

Shirley, T. R., Brune, W. H., Ren, X., et al.: Atmospheric oxidation in the Mexico City Metropolitan Area (MCMA) during April 2003, Atmos. Chem. Phys., 6, 2753-2765, 2006, http://www.atmos-chem-phys.net/6/2753/2006/.

Sjostedt, S. J., Huey, L. G., Tanner, D. J., et al.: Observations of hydroxyl and the sum of peroxy radicals at Summit, Greenland during summer 2003, Atmos. Environ., 41, 5122-5137, 2007.

Sommariva, R., de Gouw, J. A., Trainer, M., Atlas, E., Goldan, P. D., Kuster, W. C., Warneke, C., and Fehsenfeld, F. C.: Emissions and photochemistry of oxygenated VOCs in urban plumes in the Northeastern United States, Atmos. Chem. Phys. Discuss., 8, 12371-12 408, 2008, http://www.atmos-chem-phys-discuss.net/8/12371/2008/.

Stone, E. A., Snyder, D. C., Sheesley, R. J., Sullivan, A. P., Weber, R. J., and Schauer, J. J.: Source apportionment of fine organic aerosol in Mexico City during the MILAGRO experiment 2006, Atmos. Chem. Phys., 8, 1249-1259, 2008, http://www.atmos-chem-phys.net/8/1249/2008/. 
Sullivan, A. P., Peltier, R. E., Brock, C. A., de Gouw, J. A., Holloway, J. S., Warneke, C., Wollny, A. G., and Weber, R. J.: Airborne measurements of carbonaceous aerosol soluble in water over northeastern United States: method development and an investigation into water-soluble organic carbon sources, J. Geophys. Res.-Atmos., 111, D23S46, doi:10.1029/2006JD007072, 2006.

Sullivan, A. P., Weber, R. J., Clements, A. L., Turner, J. R., Bae, M. S., and Schauer, J. J.: A method for on-line measurement of water-soluble organic carbon in ambient aerosol particles: Results from an urban site, Geophys. Res. Lett., 31, L13105, doi:10.1029/2004GL019681, 2004.

Takegawa, N., Miyakawa, T., Kondo, Y., Jimenez, J. L., Zhang, Q., Worsnop, D. R., and Fukuda, M.: Seasonal and diurnal variations of submicron organic aerosol in Tokyo observed using the Aerodyne aerosol mass spectrometer, J. Geophys. Res.-Atmos., 111, D11206, doi:10.1029/2005JD006515, 2006.

Takegawa, N., Miyazaki, Y., Kondo, Y., et al.: Characterization of an Aerodyne Aerosol Mass Spectrometer (AMS): Intercomparison with Other Aerosol Instruments, Aerosol Sci. Tech., 39, 760$770,2005$.

Turpin, B. J. and Lim, H. J.: Species contributions to PM2.5 mass concentrations: Revisiting common assumptions for estimating organic mass, Aerosol Sci. Tech., 35, 602-610, 2001.

Ulbrich, I. M., Canagaratna, M. R., Zhang, Q., Worsnop, D. R., and Jimenez, J. L.: Interpretation of organic components from Positive Matrix Factorization of aerosol mass spectrometric data, Atmos. Chem. Phys., 9, 2891-2918, 2009,

http://www.atmos-chem-phys.net/9/2891/2009/.

Velasco, E., Lamb, B., Pressley, S., et al.: Flux measurements of volatile organic compounds from an urban landscape, Geophys. Res. Lett., 32, L20802, doi:10.1029/2005GL023356, 2005.

Velasco, E., Lamb, B., Westberg, H., et al.: Distribution, magnitudes, reactivities, ratios and diurnal patterns of volatile organic compounds in the Valley of Mexico during the MCMA 2002 \& 2003 field campaigns, Atmos. Chem. Phys., 7, 329-353, 2007, http://www.atmos-chem-phys.net/7/329/2007/.

Volkamer, R., Jimenez, J. L., San Martini, F., Dzepina, K., Zhang, Q., Salcedo, D., Molina, L. T., Worsnop, D. R., and Molina, M. J.: Secondary organic aerosol formation from anthropogenic air pollution: Rapid and higher than expected, Geophys. Res. Lett., 33, L17811, doi:10.1029/2006GL026899, 2006.

Volkamer, R., Molina, L. T., Molina, M. J., Shirley, T., and Brune, W. H.: DOAS measurement of glyoxal as an indicator for fast VOC chemistry in urban air, Geophys. Res. Lett., 32, L08806, doi:10.1029/2005GL022616, 2005.

Warneke, C., de Gouw, J. A., Goldan, P. D., et al.: Determination of urban volatile organic compound emission ratios and comparison with an emissions database, J. Geophys. Res.-Atmos., 112, D10S47, doi:10.1029/2006JD007930, 2007.

Warneke, C., de Gouw, J. A., Lovejoy, E. R., Murphy, P. C., Kuster, W. C., and Fall, R.: Development of proton-transfer ion trap-mass spectrometry: On-line detection and identification of volatile organic compounds in air, J. Am. Soc. Mass Spectr., 16, 1316-1324, 2005a.
Warneke, C., de Gouw, J. A., Stohl, A., et al.: Biomass burning and anthropogenic sources of $\mathrm{CO}$ over New England in the summer 2004, J. Geophys. Res.-Atmos., 111, D23S15, doi:10.1029/2005JD006878, 2006.

Warneke, C., Kato, S., De Gouw, J. A., Goldan, P. D., Kuster, W. C., Shao, M., Lovejoy, E. R., Fall, R., and Fehsenfeld, F. C.: Online volatile organic compound measurements using a newly developed proton-transfer ion-trap mass spectrometry instrument during New England Air Quality Study - Intercontinental Transport and Chemical Transformation 2004: Performance, intercomparison, and compound identification, Environ. Sci. Technol., 39, 5390-5397, 2005b.

Weber, R. J., Sullivan, A. P., Peltier, R. E., et al.: A study of secondary organic aerosol formation in the anthropogenicinfluenced southeastern United States, J. Geophys. Res.-Atmos., 112, D13302, doi:10.1029/2007JD008408, 2007.

Welsh-Bon, D., de Gouw, J. A., Warneke, C., and Kuster, W. C.: Online VOC measurements at a suburban ground site (T1) in Mexico City during the MILAGRO 2006 campaign: measurement, validation, source apportionment, and estimation of emission ratios, Atmos. Chem. Phys. Discuss., in preparation, 2008.

Wisthaler, A., Apel, E. C., Bossmeyer, J., et al.: Technical Note: Intercomparison of formaldehyde measurements at the atmosphere simulation chamber SAPHIR, Atmos. Chem. Phys., 8, 21892200, 2008, http://www.atmos-chem-phys.net/8/2189/2008/.

Yokelson, R. J., Urbanski, S. P., Atlas, E. L., et al.: Emissions from forest fires near Mexico City, Atmos. Chem. Phys., 7, 55695584, 2007, http://www.atmos-chem-phys.net/7/5569/2007/.

Zavala, M., Herndon, S. C., Slott, R. S., et al.: Characterization of on-road vehicle emissions in the Mexico City Metropolitan Area using a mobile laboratory in chase and fleet average measurement modes during the MCMA-2003 field campaign, Atmos. Chem. Phys., 6, 5129-5142, 2007,

http://www.atmos-chem-phys.net/6/5129/2007/.

Zhang, Q., Alfarra, M. R., Worsnop, D. R., Allan, J. D., Coe, H., Canagaratna, M. R., and Jimenez, J. L.: Deconvolution and quantification of hydrocarbon-like and oxygenated organic aerosols based on aerosol mass spectrometry, Environ. Sci. Technol., 39, 4938-4952, 2005a.

Zhang, Q., Jimenez, J. L., Canagaratna, M. R., et al.: Ubiquity and dominance of oxygenated species in organic aerosols in anthropogenically-influenced Northern Hemisphere midlatitudes, Geophys. Res. Lett., 34, L13801, doi:10.1029/2007GL029979, 2007.

Zhang, Q., Worsnop, D. R., Canagaratna, M. R., and Jimenez, J. L.: Hydrocarbon-like and oxygenated organic aerosols in Pittsburgh: insights into sources and processes of organic aerosols, Atmos. Chem. Phys., 5, 3289-3311, 2005b, http://www.atmos-chem-phys.net/5/3289/2005/. 